\title{
The Emamzadeh Yahya at Varamin: A Present History of a Living Shrine, 2018-2o
}

\author{
Keelan Overton \\ Independent Scholar, Santa Barbara, CA, USA \\ keelanoahu@yahoo.com \\ Kimia Maleki \\ Graduate Student, History of Art, Johns Hopkins University, \\ Baltimore, MD, USA \\ kmalekiı@jhu.edu
}

\begin{abstract}
The Emamzadeh Yahya at Varamin, a tomb-shrine located south of Tehran, is well known for supplying global museums with iconic examples of Ilkhanid-period luster tilework. After providing a historiography of the site, including its plunder in the late nineteenth century, we explore its current (2018-20) "life" in order to illuminate the many ways that it can be accessed, used, perceived, and packaged by a wide range of local, national, and global stakeholders. Merging past and present history, art history and amateur anthropology, and the academic, personal, and popular voice, this article explores the Emamzadeh Yahya's delicate and active existence between historical monument, museum object, sacred space, and cultural heritage.
\end{abstract}

\section{Keywords}

Emamzadeh Yahya (Imamzada Yahya) - Varamin (Veramin, Waramin) - Iran - Ilkhanid shrine - luster - tilework - mihrab - museums - present history - COVID-19

The Emamzadeh Yahya at Varamin $(35.31614,51.648336)$ poses a number of art historical conundrums. Despite the fact that it is located just 35 miles south of Tehran and its Ilkhanid period (1256-1353) luster tilework enjoys endless visibility online, in print, and in museums (fig. 1), the shrine itself remains relatively anonymous beyond its immediate demographic and specialist research. In the age of ongoing renovations of Islamic art galleries, we expect to see its famous tiles redisplayed and reevaluated, but the complex's history and interpretation tend to end at its moment of rupture in the late nineteenth century, when its tilework was systematically removed and dispersed across the globe. The opening description of the emāmzädeh on MIT's Archnet - an open access, visual database surveying architectural sites across the Muslim world - paints a dismal picture: "Originally part of a larger shrine complex including an octagonal tomb tower and entrance portal, the remaining naked tomb shrine is victim of over one hundred years of looting." ${ }^{1}$ This begs the questions: How has the complex fared since? What is its present reality?

Building on substantive research of the Emamzadeh Yahya as an Ilkhanid monument, this article redirects attention to its current circumstance. ${ }^{2}$ Who are its visitors 


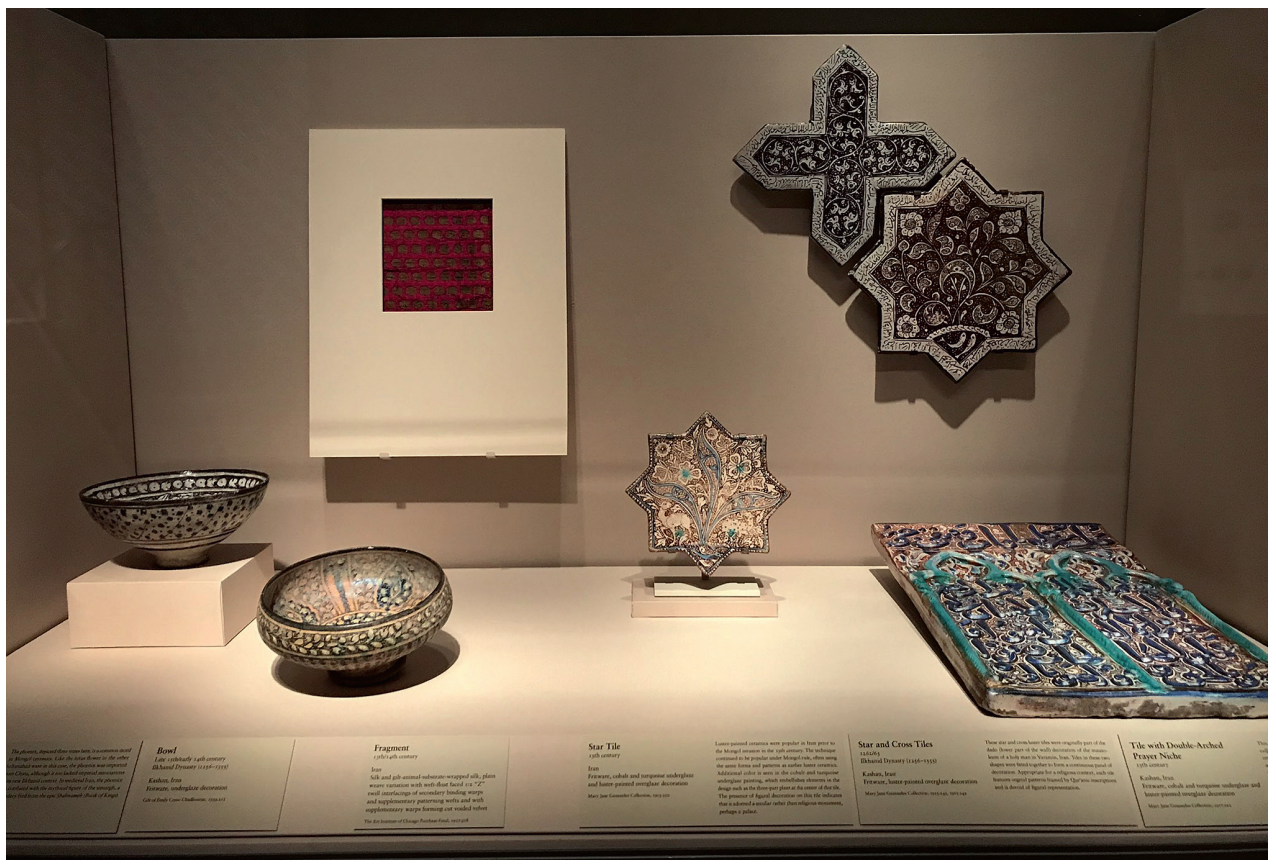

and audiences? How has the shrine responded to its vexed past? What are its imminent concerns? While it is hoped that this study might contribute to future reconciliations of the tomb's tilework and walls, hence improving understanding of its Ilkhanid aesthetic, we are primarily concerned with how the shrine complex as a whole looks, ticks, and functions in the present. Like all fieldwork conducted in Iran, our research is the product of specific contingencies and timing, some more dramatic than others. While we were able to visit the shrine in 2018 and 2019 under relatively normal circumstances, the outbreak of COVID-19 in February 2020 forced an adjustment of our present history in light of the "new normal." After providing a historiography of the Emamzadeh Yahya, we recount our respective experiences of the site in order to illuminate the many ways that it can be (and has been) accessed, used, perceived, and packaged by a wide range of local, national, and global stakeholders. Merging past and present history, art history and amateur anthropology, and the academic, personal, and popular voice, we explore the Emamzadeh Yahya's delicate existence between historical monument, museum object, sacred space, and cultural heritage. ${ }^{3}$

\section{Historiography}

The Emamzadeh Yahya is one of many emāmzādehs, or tombs of descendants of one of the Twelve Imams, that sprinkle the Iranian landscape. Its commemoration of Emamzadeh Yahya (d. ca. 9oo), a sixth-generation descendant of the second Imam Hasan b. 'Ali (d. 670), makes it somewhat unique as most emāmzādehs are dedicated to descendants of the seventh Imam Musa b. Jaffar al-Kazim (d. 799). When Jane Dieulafoy (d. 1916) visited the Emamzadeh Yahya in 1881, it included a monumental entrance portal, an octagonal tower with a conical roof on the west side, and the main tomb on the south, all of which are visible in a woodcut published in her 1887 travelogue. ${ }^{5}$ Based on this woodcut, Donald Wilber proposed a hypothetical plan of the complex. ${ }^{6}$

The only extant historical structure of the Emamzadeh Yahya is the tomb proper, a domed square surrounded by smaller vaulted rooms added at a later date. ${ }^{7}$ Between 1260 and 1310, when Varamin was the Ilkhanid capital of Rayy (Rey) province, the interior of
FIGURE 1

Pair of star and cross tiles (upper right) from the Emamzadeh Yahya at Varamin on display in the Art Institute of Chicago PHOTO: KIMIA MALEKI, 2018 
the tomb was decorated in the finest materials and techniques of the day: twice-fired luster tilework and carved and painted stuccowork. As elucidated by Sheila Blair, one of its known patrons was Fakhr al-Din, the local ruler (mālek) of Rayy and Varamin and a court favorite under Ghazan (r. 1295-1304) and Uljaytu (r. 1304-16). ${ }^{8}$ Fakhr alDin's most conspicuous contribution to the tomb is the large band of stucco epigraphy that wraps the interior at mainly eye level. It begins with Q 62:1-4 (glorifying God, His Messenger, and His Sacred Word), is followed by Fakhr al-Din's name and the date of Muharram 707/July 1307, and concludes with a hadith: "Whoever does a good deed for one of the children of 'Abd al-Muttalib [d. 578, grandfather of the Prophet Muhammad] in this life and is not rewarded for it, Allah shall reward him on the Day of Resurrection instead. The Messenger of Allah said the truth."9 Fakhr al-Din also patronized the nearby tomb tower of his father 'Ala' al-Din (688/1289-9o; 35.324943, 51.645684), and Blair has suggested that his father or grandfather may have been responsible for the first stage of the Emamzadeh Yahya's decoration in the 126os, thus making its patronage over five decades a family affair. ${ }^{10}$ Fakhr al-Din's legacy in Varamin extended to his protégé 'Izz al-Din Quhadi, who constructed the city's well-known congregational mosque (722-6/1322-6; 35.322017, 51.641664), the only surviving Ilkhanid example of its kind in Iran. ${ }^{11}$

Outside of Varamin and specialist scholarship, the Emamzadeh Yahya is best known for the luster tilework that once decorated the walls of the tomb and is now dispersed across the globe. This revetment was made by master potters in Kashan between 1262 and 1305 and ordered for the tomb's dado, mihrab, and cenotaph. The dado included interlocked stars and crosses distinguished by their large size (star: $31.6 \times 31.3 \mathrm{~cm}$; cross: $21.8 \times 21.7 \mathrm{~cm}$ ), palette of white and luster alone (compare the stars in fig. 1), and diminutive Quranic inscriptions sometimes dated between Dhu l-Hijja 66o and Safar 661/ October-December 1262. In his seminal Persian Lustre Ware (1985), Oliver Watson recorded over 150 examples in some twenty-four collections. ${ }^{12}$ Today, this figure is closer to thirty repositories, if not more, and includes museums in such cities as Doha, St. Petersburg, Tbilisi, London, Oxford, Paris, Glasgow, Baltimore, Chicago (fig. 1), Los Angeles, Tokyo, and probably even Tehran. ${ }^{13}$ The twelve foot tall mihrab (151 $3 / 8 \times 90$ $\times 81 / 2$ in.) is composed of more than sixty tiles, includes eight distinct sets of Quranic inscriptions, and is dated Sha'ban 663/May 1265 and signed by 'Ali b. Muhammad b. Abi Tahir. It is preserved in Shangri La, the Honolulu home of the American collector Doris Duke (d. 1993) now open to the public and operated by the Doris Duke Foundation for Islamic Art. ${ }^{14}$ The four-piece panel that once covered the top of the cenotaph names the deceased, includes Quranic inscriptions, and is dated 10 Muharram 705/August 2, 1305, signed by Yusuf b. 'Ali b. Muhammad b. Abi Tahir (son of the previous), and in the State Hermitage Museum in St. Petersburg..$^{15}$ This panel would have been surrounded by a series of borders, and the sides of the cenotaph would have also been revetted in tiles of various shapes and techniques. The cenotaph as a whole must therefore be reimagined as a sizeable rectangular box. ${ }^{16}$

During the late nineteenth century, all of this tilework was systematically removed from the tomb and soon appeared in European cities. Tomoko Masuya has concluded that the plunder of the Emamzadeh Yahya occurred in two phases: before 1875 and between 1881 (Dieulafoy's visit, when the mihrab and cenotaph were apparently in situ) and 1900 (when the mihrab was in Paris and exhibited at the Exposition Universelle). ${ }^{17}$ Some of the removals thus occurred after the Qajar government had issued an edict protecting religious buildings in 1876 , which was inspired by growing concerns about the stripping of tilework from sacred sites, as observed by Dieulafoy. ${ }^{18}$ The Emamzadeh Yahya was not alone in suffering this fate, and similar lootings occurred at mosques, emāmzādehs, and Sufi shrines in Kashan, Qom, and Natanz. 
The illicit removal of sizeable amounts of luster tilework from Iranian tomb-shrines and mosques involved an entangled web of actors and complicity. Depending on the site in question, responsibility for the initial act of plunder rests with the actual looters and possibly also local interlocutors. ${ }^{19}$ This arduous process entailed the deconstruction of vast walls and surfaces piece by piece. Some tiles would have been large and heavy (consider those forming the hood of a mihrab), while other smaller shapes (stars, crosses, bow ties, octagons) would have been interlocked with their neighbors and required delicate removal to avoid breakage. Processes of transport and export likely involved Tehran-based government officials and concessions. ${ }^{20}$ Finally, we must consider the wider chain of supply and demand, including internal and external dealers, agents, collectors, and museums.

Moya Carey's recent study of the Persian collections in the Victoria and Albert Museum (V\&A) illuminates some of these entanglements. ${ }^{21}$ She traces how the then South Kensington Museum was aware that a set of fifty-two luster tiles purchased in 1875 from the Tehran-based French photographer-instructor Jules Richard (d. 1891) was a "sensitive acquisition." 22 The museum's buying agent Robert Murdoch Smith (d. 1900) expected that a law would be passed to protect sacred sites - indeed, the 1876 one - and declined the museum's request for photographs of the original buildings as "impossible." ${ }^{23}$ Regarding a three-piece luster panel that once covered a cenotaph and is comparable to the Emamzadeh Yahya (Hermitage) example, Murdoch Smith was told that it had been "hidden underground until an opportunity of smuggling it into Teheran could be found." 24

All together, the luster tilework of the Emamzadeh Yahya is a staple of scholarship on the ceramics industry of medieval Kashan as well as later histories of collecting. The mihrab is particularly famous as one of just six surviving intact examples dated between 612/1215 and 734/1334. Doris Duke purchased it in 1940 from Hagop Kevorkian (d. 1962), and it remains on view in Shangri La's "Mihrab Room." The five others are likewise preserved in museums - three in the Central Museum of the Shrine of Imam Reza (Āstān-e Quds-e Rażav̄) at Mashhad (fig. 2) and one each in Tehran's Islamic Museum and Berlin's Museum of Islamic Art. ${ }^{25}$ Whereas the Varamin (Honolulu) and Kashan (Berlin) mihrabs were illicitly removed and exported during the late nineteenth century, the three now in the Mashhad shrine museum were transferred there in the late 1970s for purposes of preservation. ${ }^{26}$ The history of the mihrab now in Tehran's Islamic Museum is more complicated. Its original home - the Emamzadeh 'Ali b. Ja'far at Qom was denuded during the nineteenth century. The mihrab and parts of the cenotaph were acquired by the National Museum of Iran in the 193os, and most of the rest of the revetment is in the Shrine Museum of Fatima Masumeh at Qom. ${ }^{27}$ Today, the mihrab is on view in a gallery of Tehran's Islamic Museum inclusive of a stucco mihrab from Oshtorjan (707/1308), and this museum includes innumerable other luster tiles from both known and anonymous sites. It is thus important to reiterate that the preservation, and by extension decontextualization, of luster tilework is not just the purview of foreign museums, but also part and parcel of Iranian collections of all kinds, including site museums (e.g., Mashhad, Qom, Takht-e Suleyman), the National Museum in Tehran, regional museums (e.g., the Azerbaijan Museum in Tabriz), and private collections. The key differences between Iranian and foreign museums rest in processes of acquisition and the fact that only the latter preserve collections that might warrant consideration for repatriation.

Due to the inherent deconstructability of a luster mihrab - most are composed of fifty to sixty individual tiles secured to the wall with mortar - its physical fate could vary dramatically upon removal. In the six cases mentioned above, the mihrab survived relatively intact in its new museum context. By contrast, the fifty to sixty tiles once forming

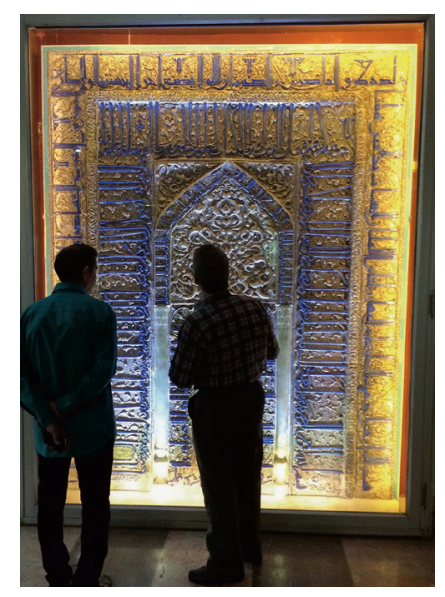

FIGURE 2

Luster mihrab signed by Abu Zayd and Muhammad b. Abi Tahir and dated Rabic II 612/August 1215. Originally in the tomb of Imam Reza in the Shrine of Imam Reza at Mashhad, it is now on display in the Central Museum of Astan-e Quds-e Razavi

PHOTO: KEELAN OVERTON, 2014 


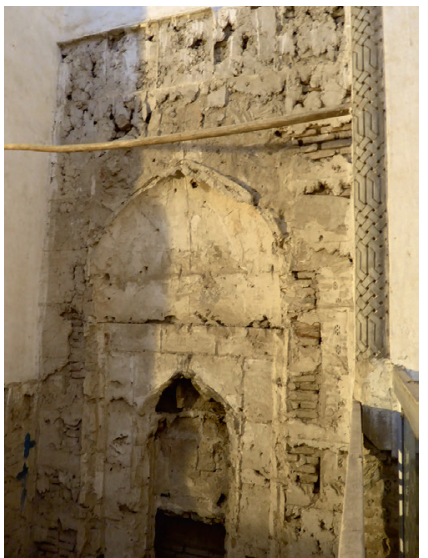

FIGURE 3

Mihrab void in the tomb of Shaykh 'Abd al-Samad (d. 1299) at Natanz. Visible are the impressions of the $\sim 50-60$ individual tiles that once formed the luster mihrab

PHOTO: KEELAN OVERTON, 2016 the luster mihrabs in the mosque and tomb (fig. 3) of the shrine of Shaykh 'Abd alSamad at Natanz (704-25/1304-25) were dispersed across collections and often remain unidentified as parts of a mihrab. The imprints left behind by their mortar (fig. 3) are among the best "maps" for their virtual reconstruction, as are their once continuous Quranic inscriptions. ${ }^{28}$ In recent years, scholars have retraced the external trails and travails of the Kashan, Natanz, and Varamin mihrabs through a close reading of European and American sales catalogs and museum archives. ${ }^{29}$ For the Kashan case, a critical internal perspective has also been provided by the Kashan-based potter Abbas Akbari, who has revived the luster technique, reinterpreted the Kashan (Berlin) mihrab on his own terms, and conducted research on historical sites in and around Kashan. ${ }^{30}$

It is not an exaggeration to say that the luster tilework of the Emamzadeh Yahya has effectively "made" the monument in art historical circles. The shrine's tiles are literal "world heritage" in the sense that they are dispersed across the globe and seen by international audiences on a regular basis. In the museum, they are consumed as autonomous works of art and often exhibited alongside luster tiles from other sites. Such displays prioritize the luster technique over architectural context (fig. 1) and at times parallel those found in late nineteenth and early twentieth-century sales catalogs. ${ }^{31}$ In most museum labels, information on the tomb is typically limited to the basic provenance phrase "from the Emamzadeh Yahya, Varamin," which is relatively meaningless to most general audiences, or a slightly more descriptive version: "Part of the dado (lower part of the wall) decoration of the mausoleum of a holy man in Varamin, Iran" (as in fig. 1). ${ }^{32}$ The finest tiles have been professionally photographed and are then posted to museum websites, where they enter the realm of infinite replicability under "fair use." A case in point is the panel of star and cross tiles in the V\&A, which is available as a free high-resolution download and often reproduced in print. ${ }^{33}$

In contrast to its highly visible luster tiles, the Emamzadeh Yahya itself is relatively under seen and selectively reproduced. The section on the shrine in the Ganjnameh, the multi-volume encyclopedia of Iranian Islamic architecture, exemplifies its typical visual curation as a historical monument: plans and elevations of the tomb, a general view of the tomb's façade, and details of its finest interior passages, including the upper qibla wall and zone of transition toward the dome, a corner niche and squinch, and the stucco epigraphic band. ${ }^{34}$ Archnet features two exterior views of the tomb and one detail of the stucco band, and the website of the Iran Tourism and Touring Organization (IтTо) includes three aerial views of the tomb, a detail of a squinch, and the aforementioned panel of tiles in the V\&A. ${ }^{35}$ In some publications, images of the displaced tilework are the sole visual representations of the site. ${ }^{36}$ This is not surprising since museum photography is often readily available, as noted above, and many tilework panels are more impressive "works of art" in reproduction than the tomb's modest and reworked façade. It also goes without saying that images of the bare walls left behind in the tomb are not exactly coveted in textbooks and museum monographs, which tend to favor the pristine and present the best "face" of a topic to general audiences.

With this existing visual canon in mind, the personal journeys narrated below focus on aspects of the Emamzadeh Yahya that are not typically reproduced and discussed in art historical scholarship: its function as a living sacred space and the "ghosts" of its luster tilework. ${ }^{37}$ Although we both first learned of the shrine through its tiles preserved in museums, our site visits in 2018 and 2019 differed according to many factors, including timing, oversight, and varying levels of insider/outsider-ness. The outbreak of COVID-19 in February 2020 transformed our anticipated visits in 2020 into an entirely remote exercise, and we have allotted a final section to exploring patterns of religiosity and adaptability within the "new normal." Notwithstanding some of its limitations and 
unforeseen directions, this research will hopefully contribute to the reseeing, reappreciation, and reknowing of the Emamzadeh Yahya in the twenty-first century.

In April 2018, I left Tehran for the approximately one hour drive south to Varamin. I was in Iran on a twenty-two-day tourist visa and was accompanied by Mojgan Attarzadeh, an Iranian national guide and colleague with whom I would lead a pending tour for the Asian Art Museum of San Francisco. I had visited the shrine of Shaykh 'Abd al-Samad at Natanz in 2014 and 2016 and remained haunted by the visceral scars of its looted tilework (fig. 3) and the general "deadness" of the Ilkhanid tomb and mosque. How had the Emamzadeh Yahya fared by comparison? Had it likewise been deactivated as a sacred space? I had served as Shangri La's Curator of Islamic Art in 2011-12 and was eager to (finally) see the mihrab's original home. We also needed to scout the emāmzädeh and two other nearby sites - the congregational mosque and tomb tower of 'Ala' al-Din - for a formal visit a few days later with the tour group. Despite her decades of experience leading cultural tours for foreign museum and university groups, Ms. Attarzadeh had not visited Varamin either. Suffice it to say that the city is not a standard stop on most foreign tourist itineraries. ${ }^{38}$

The Emamzadeh Yahya is located in the Kohneh Gol neighborhood of southern Varamin, and its main entrance is approached from the north, just off of the Varamin-Tehran highway (\#1 in fig. 4). ${ }^{39}$ The urban fabric in front of the shrine has been cleared and paved, and there is ample space for parking. A low brick wall decorated with pious invocations encloses the rectangular site, and a tiled entrance gate (pisshtāq) in neo-Safavid style identifies it as an āstān-e moqaddas (fig. 5). This gate is relatively recent (post-Revolution) and replaced a modest version in place as of 1978, when the area to the north was still a field. ${ }^{40}$ The emāmzädeh was registered as a national monument in $1313 \mathrm{sh} / 1935$, during the early Pahlavi period (1925-79), and is one of about eighty registered sites in Varamin alone. ${ }^{41}$

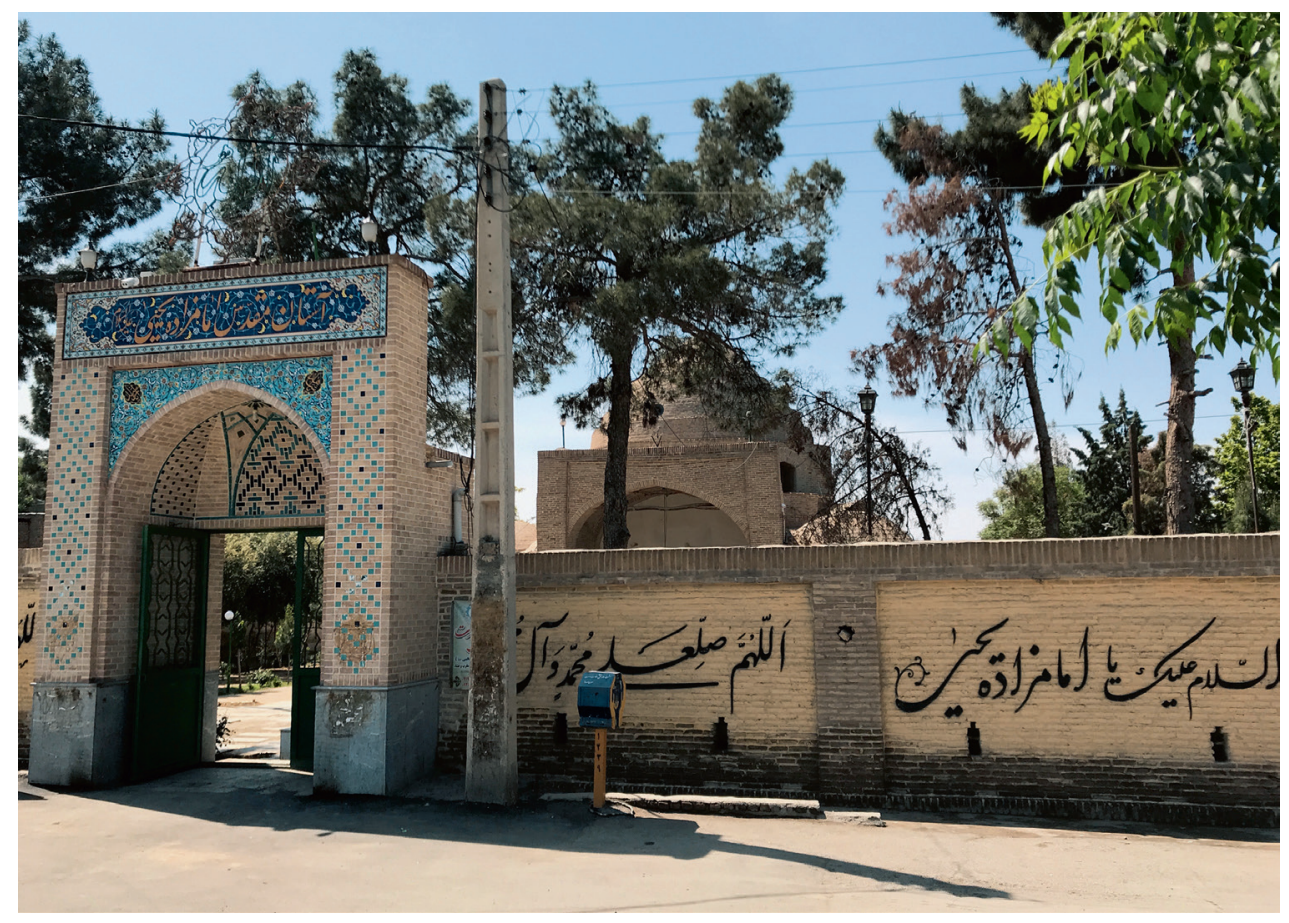

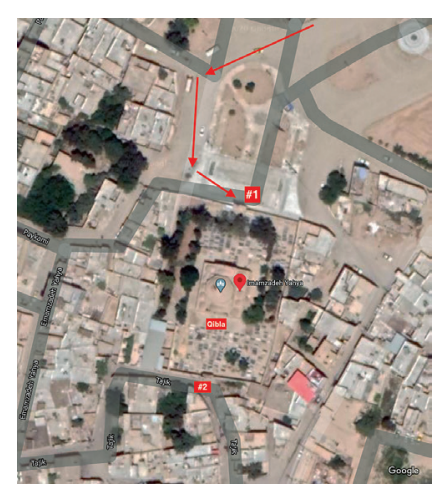

FIGURE 4

Google satellite view of the Emamzadeh Yahya at Varamin. The red arrows mark a typical approach to the shrine from Tehran. \#1 is the main (north) entrance gate of the walled complex. \#2 is a smaller gate on the southern (qibla) side PHOTO: ANNOTATED BY KEELAN OVERTON, 2020

FIGURE 5

Main (north) entrance of the Emamzadeh Yahya at Varamin. A post-Revolution tiled portal (pīshtāq) in neo-Safavid style announces the site as the "Holy Shrine of Emamzadeh Yahya" PHOTO: KEELAN OVERTON, 2018 
FIGURE 6

Façade of the tomb of

Emamzadeh Yahya, just after passing through the entrance gate PHOTO: KEELAN OVERTON, 2018

FIGURE 7

View of the tomb from the northeast corner of the courtyard, capturing various ground-level tombstones. The red arrow indicates one of the marble tombstones mounted on the tomb's façade

PHOTO: KIMIA MALEKI, 2019
Upon passing through the tiled gate, one enters a large courtyard and immediately faces the well-published façade of the tomb (fig. 6). The courtyard is in fact a cemetery filled with predominantly ground-level tombstones on east-west alignment, hence parallel to the qibla (the direction of Mecca, technically $220^{\circ}$ ) (figs. 6-7). The domed tomb sits in the middle of this enclosure, and some older historical tombstones have been reinstalled on its façade (see the red arrow in fig. 7). The courtyard behind the
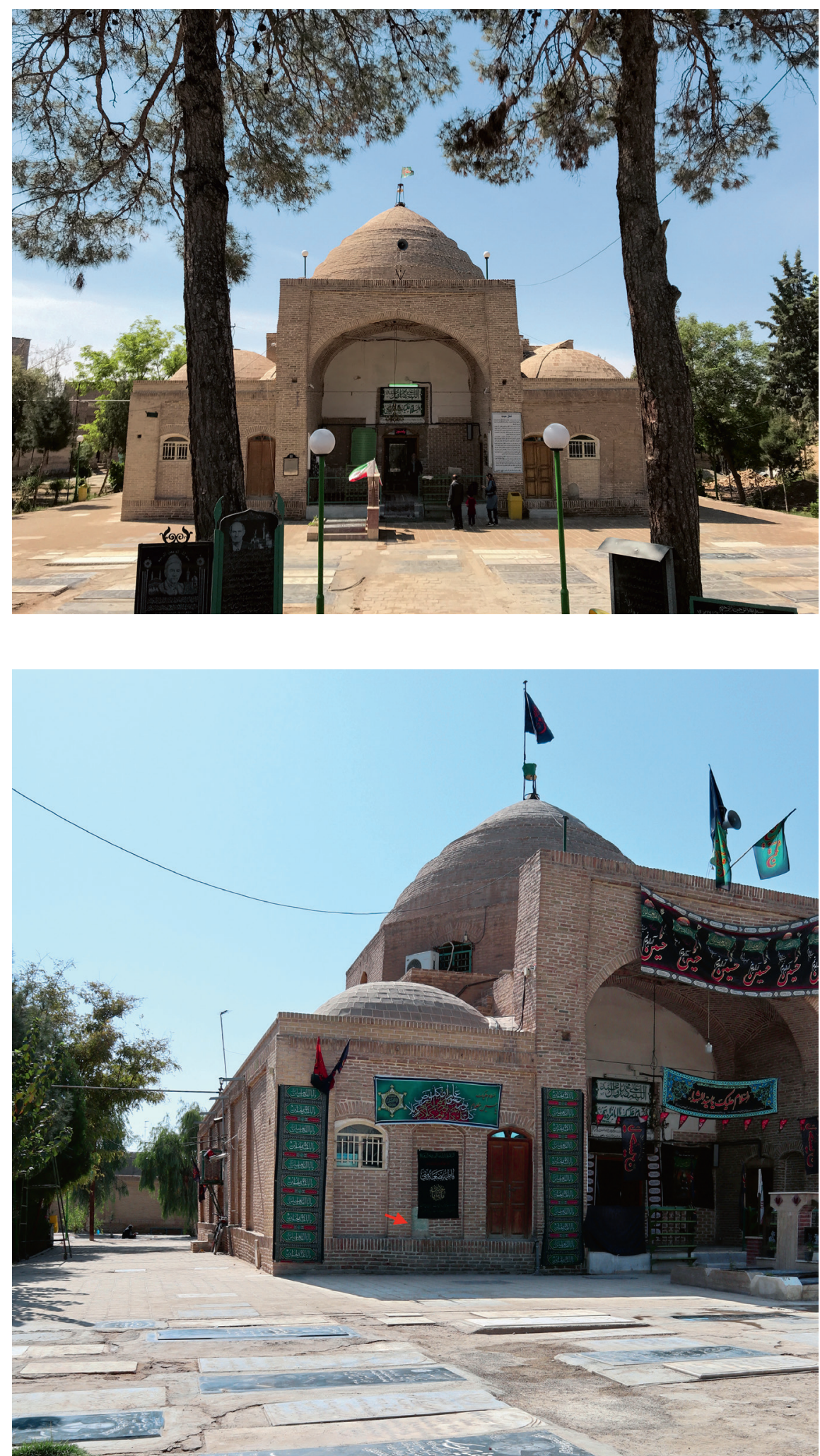
qibla wall is likewise home to many tombstones. An additional modest gate provides access from the south (\#2 in fig. 4) and is approached through the narrow streets of the neighborhood.

Walking across the uneven tombstones of the courtyard toward the entrance of the tomb, I realized that this would be a much different experience from the Natanz shrine. Whereas the tomb of Shaykh 'Abd al-Samad is effectively "dead" as a sacred space, the Emamzadeh Yahya is alive and well. As I entered the tomb beneath an electronic sign flashing Yä Hossein and passed through a split sheet of hanging plastic, I was immediately struck by the intimacy and serenity of the space. This was far more than a "naked tomb shrine" and "victim of over one hundred years of looting." 42 Nor was it a sanitized, cookie-cutter tourist site. I was wary of being intrusive, but the shrine attendant soon welcomed us, and for the duration of our visit, we were just two of three visitors (the other was a local woman conducting her personal prayers).

The center of the chamber is engulfed by an octagonal $\dot{z}$ arịh, a pierced screen that encloses and protects the cenotaph within. Swaths of green fabric attached to the $\dot{z}$ arì divide the space by gender and direct the visitor to the left (women) or right (men).

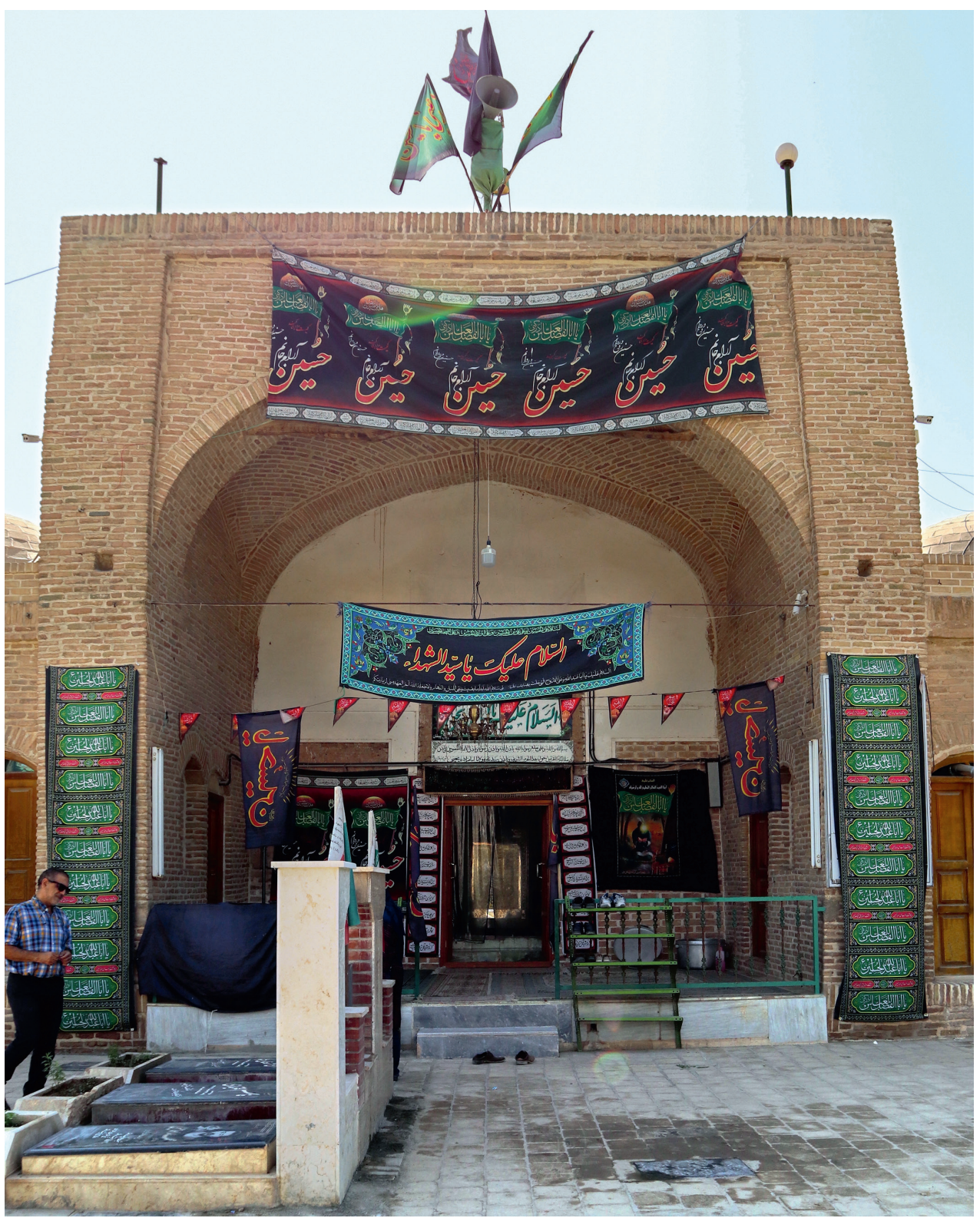

FIGURE 8

Detail of the entrance of the tomb decorated with flags and banners during Muharram (compare to fig. 6)

PHOTO: KIMIA MALEKI, 2019 
FIGURE 9

Dome, zone of transition, and stucco decoration immediately above the tomb's mihrab PHOTO: KIMIA MALEKI, 2019

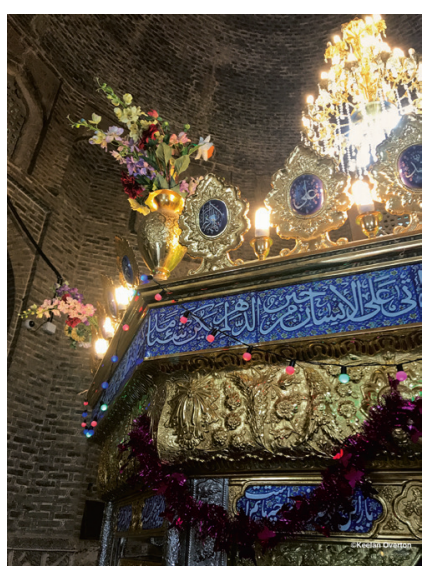

FIGURE 10

Top of the żarịh decorated with flowers, lights, and garlands. In the distance is the large chandelier that hangs from the center of the dome PHOTO: KEELAN OVERTON, 2018

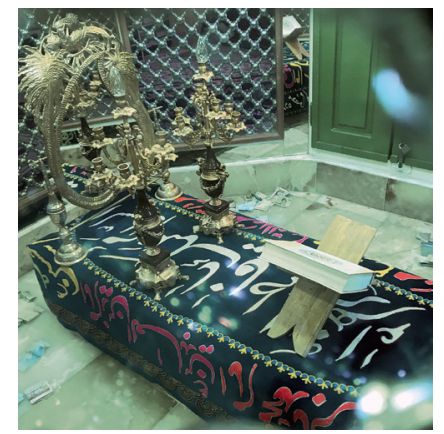

FIGURE 11

Looking through the $\dot{z}$ arịh toward the current cenotaph of Emamzadeh Yahya

PHOTO: KEELAN OVERTON, 2018

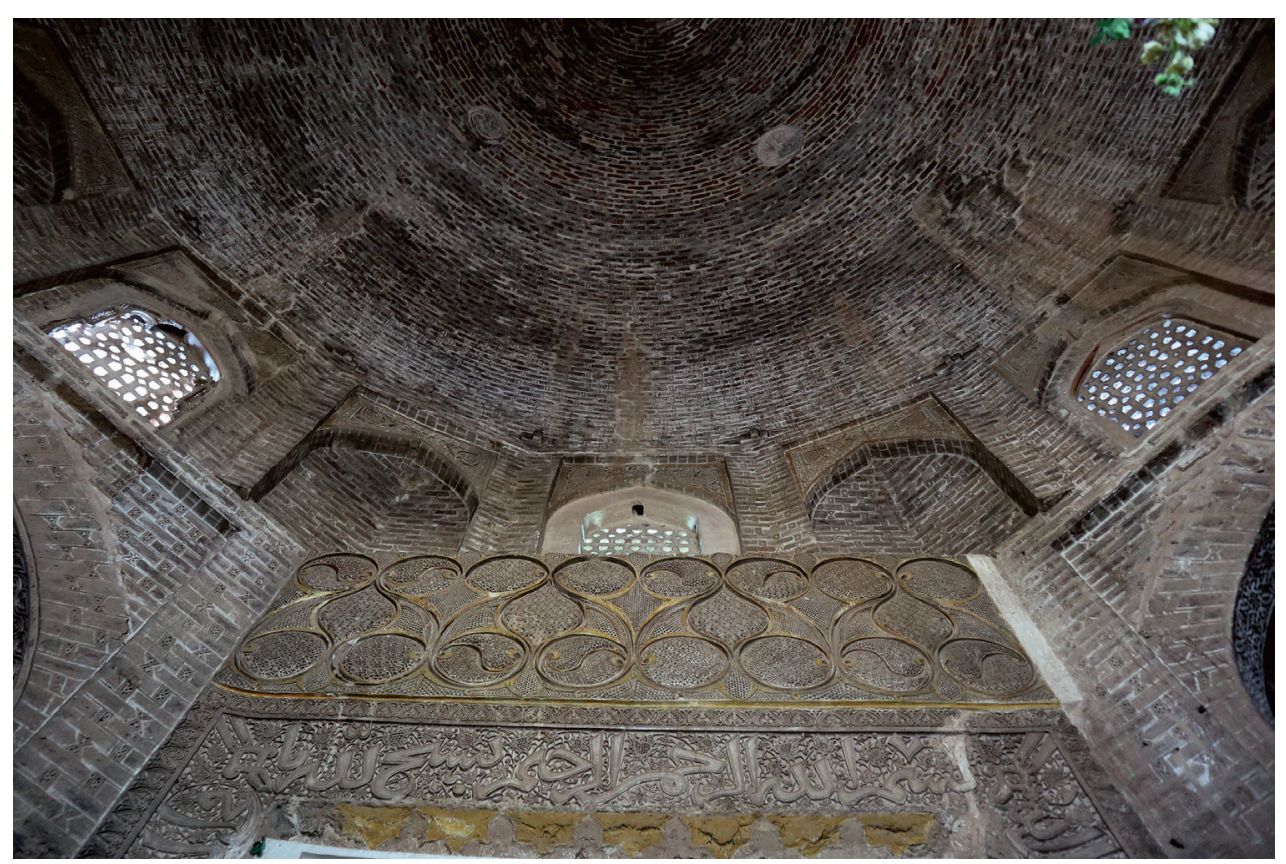

Looking up to the squat plain dome, its 16-sided zone of transition features blind arches alternating with pierced grills once inset with colored glass (fig. 9). The four corners of the room are deep niches topped by elaborate squinches decorated with panels of carved and painted stucco. Abundant yellow is still visible, but all of the squinches have large vertical cracks that have been recently restored. As noted above, these architectural features are commonly reproduced online and in print.

The $\dot{z}$ arĭh is a ubiquitous feature of living tomb-shrines in Iran and the focus of many

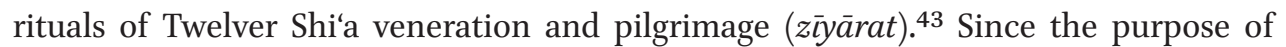
$z \bar{y} \bar{a} r a t$ is for the pilgrim $(z \bar{a} e r)$ to gain proximity to the baraka of the deceased, offer prayers in his/her honor, and request intercession in various aspects of daily life, it is common for worshippers to touch and kiss the żarịh, pray against it, offer money through its voids, tie votive cloth to it, and sometimes circumambulate it (these rituals are site specific). Like many żarịhs in Iranian shrines, the example in the Emamzadeh Yahya is gilded in silver and gold, covered in inscriptions, and lovingly decorated with fairy lights, garlands, and vases of faux flowers (fig. 10). The side facing the entrance features a foundation inscription dated $1389 \mathrm{sh} / 2010$ recording that the work was done during the villāyāt (lit. guardianship) of Grand Ayatollah Khamenei. The top of the żarịh features a continuous band of Quranic inscriptions in white sols (Ar. thulth), and poetic verses in nasta li $q$ are set in cartouches below. The cenotaph within is covered with an inscribed black textile and several objects sit on its surface, including a large mirror, candlesticks, and a Quran on a rahl (stand) (fig. 11). Paper bills donated by the pious sprinkle the surrounding marble floor.

The relatively narrow ambulatory around the żarịh is covered in carpets, and pillows are propped up against the walls to support reclining visitors (figs. 12-13). Functional objects, furnishings, and decorations are on full display - bookshelves overflowing with books, mirrors, framed calligraphies and images, vases of flowers, piles of floral chadors (women's side), a large chandelier hanging from the dome, prayer beads (tasbih), and boxes filled with mohr (lit. seal; Ar. turbah, lit. soil). These prayer stones are made from the sacred soil of Karbala and are an integral component of Shi'a prayer (during complete prostration, the forehead touches them; see those on the carpet in fig. 13). Also 
visible throughout the small chamber are the trappings of daily upkeep - dusters, air conditioners, vacuums, and electrical cords.

Walking around the $\dot{z}$ arịh, one quickly approaches the rear wall of the tomb. It takes little imagination to deduce the original location of the luster mihrab: a looming white ghost marks its original position on the qibla wall (fig. 14). The stucco band completed in 707/1307 would have framed it on three sides and begins and ends in the upper right with the basmala and hadith, respectively. Directly above is an outstanding stucco panel with bold yin-yang motifs meticulously filled with Ilkhanid-style strapwork and geometric patterning. This panel is at equal height to the corner niches and immediately above is the 16 -sided zone of transition. In reproduction, the mihrab void is typically cut out of views of the upper qibla wall toward the dome (as in fig. 9).

Looking at the void from a skewed angle on either side of the ambulatory (only female visitors were present so I was free to go on both sides), I was struck by the enormity of the mihrab (fig. 14). It did not need to be that large, and its size further demonstrates the significance of both Varamin and the shrine during the Ilkhanid period, as emphasized by Sheila Blair. ${ }^{44}$ I also could not help but recall the mihrab on view at Shangri La. There, a go-degree turn to the right points one toward the dining room and Pacific Ocean beyond, and at one's back is an arch framed by architectural elements custom-made in Morocco that leads into a living room facing a pool, Playhouse, and ultimately Diamond Head crater. ${ }^{45}$ The mental juxtaposition was bizarre and unsettling, but this disconnect between original context and adopted sphere is by no means unique to Shangri La. The other five luster mihrabs exist in similarly decontextualized states in their respective museums in Mashhad (fig. 2), Tehran, and Berlin, albeit in varying degrees of physical and interpretive distance from the source site. What sets the Shangri La display apart is that it is not a traditional white cube, but rather conceived by Doris Duke within the context of her then private home. ${ }^{46}$

In contrast to the mihrab void at Natanz, where the imprints of the 50-6o luster tiles once comprising the niche are on full display as if they were stripped yesterday (fig. 3), the Varamin scars have been covered in smooth white plaster, divided into two arches, and populated with a variety of didactics (fig. 14). ${ }^{47}$ The most practical are printed and hand-drawn qibla signs whose modesty in comparison to the tiled masterpiece that once served the same function cannot help but give one pause (fig. 15). Nonetheless, they provide a critical update for the visitor. Each is tilted slightly to the right to indicate the accurate qibla, and the hand-drawn example further reads "a little to the right" (kamì be-rāst [sic])... twenty degrees." Beneath is a textual genealogy of Emamzadeh Yahya based on Shi'a sources (fig. 16), and on either side is a collage of four images (fig. 17). ${ }^{48}$ On top are the two woodcuts published in Dieulafoy, including the general view of the complex that has served as the crux of its hypothetical plan. ${ }^{49}$ On the bottom are photographs of the tomb's tiles on display in the Hermitage, including the panel naming Emamzadeh Yahya that once covered the top of his cenotaph.

At the very top of the mihrab void is a diminutive yet potent reminder of the luster tilework: a small fragment $(3 \times 3 \mathrm{in}$.) of the triangular tip of a luster cross presumably salvaged from the dado and deliberately mounted in this prominent location (fig. 15$){ }^{50}$ In the conventional museum display, such crosses are generally in excellent condition and often paired with their adjacent stars (fig. 1). The difference in messaging between the two displays - fragmentation and memory in the tomb versus wholeness and beauty in the museum - throws into sharp relief the conditional nature of interpretation and the often seismic disconnect between architectural sites and the museums preserving their surface revetment.

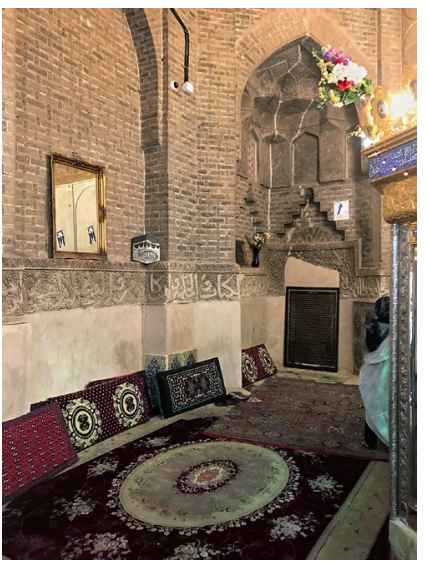

FIGURE 12

East ambulatory (women's side) of the tomb, immediately after entering the building and turning left to avoid the żarịh (visible on the right). The squinch of the southeast corner is visible in the background

PHOTO: KEELAN OVERTON, 2018

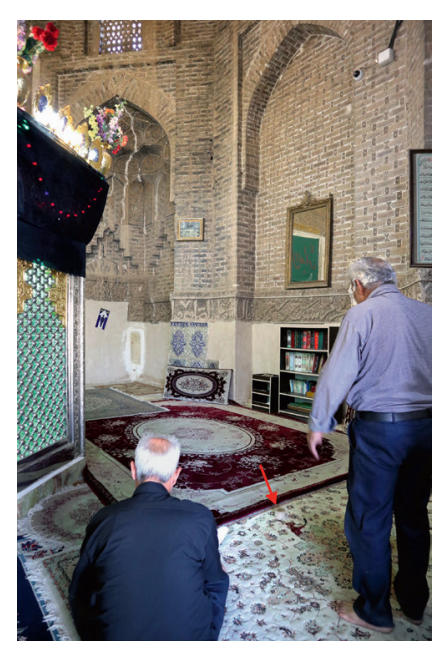

FIGURE 13

West ambulatory (men's side) of the tomb, immediately after entering the building and turning right to avoid the $\dot{z}$ arịh (visible on the left). The red arrow marks prayer stones (mohr) on the carpeted floor PHOTO: KIMIA MALEKI, 2019 
FIGURE 14

View of the qibla wall (south) and mihrab void from the west side of the tomb. This space once housed the luster mihrab signed by 'Ali b. Muhammad b. Abi Tahir and dated Sha'ban 663/May 1265, today preserved in the Doris Duke Foundation for Islamic Art (Shangri La) in Honolulu PHOTO: KEELAN OVERTON, 2018

FIGURE 15

Detail of the top of the mihrab void. The stucco epigraphic band dated Muharram 707/July 1307 begins on the upper right with the basmala, followed by the beginning of Q: 62. The red arrow marks a fragment of a luster cross salvaged from the dado

PHOTO: KEELAN OVERTON, 2018
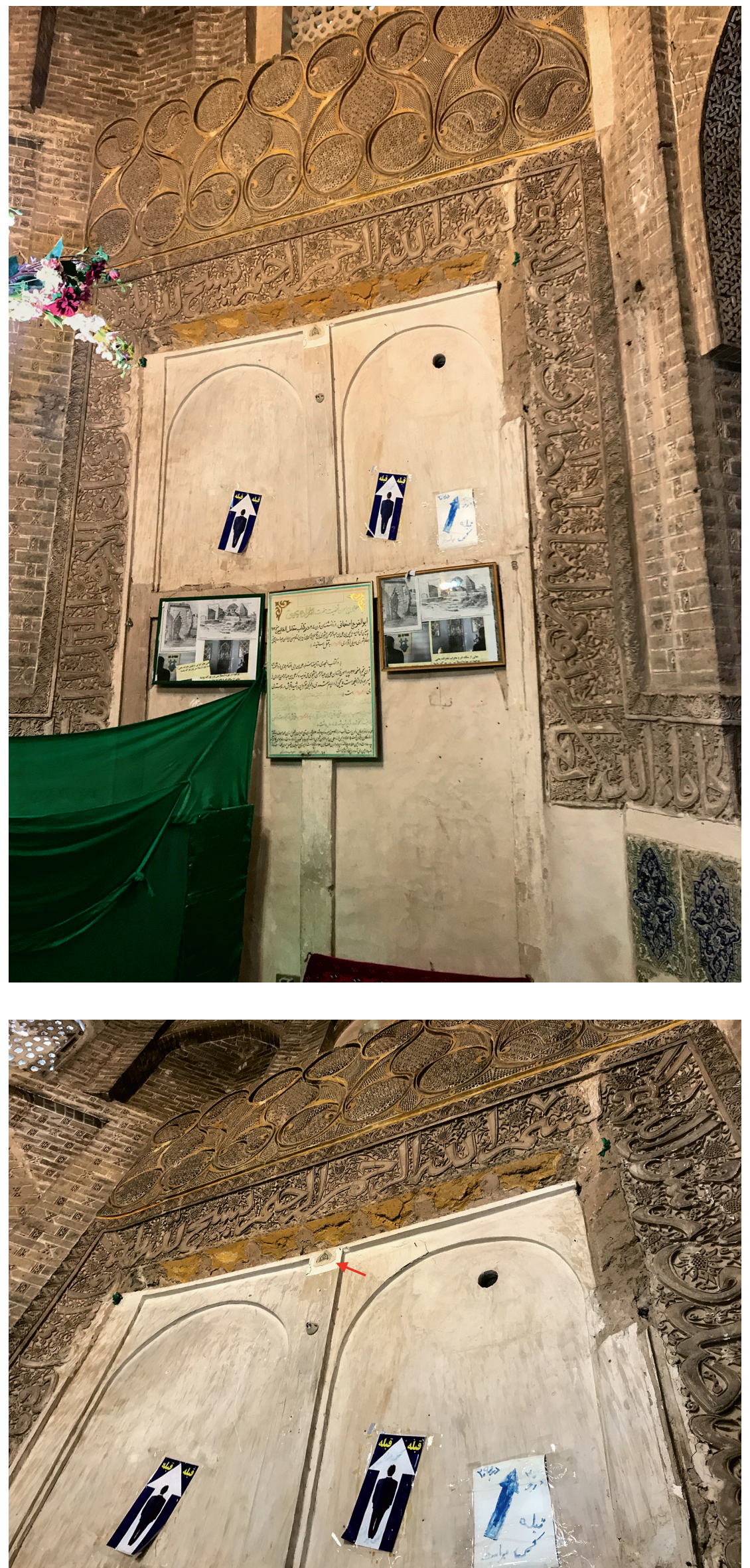

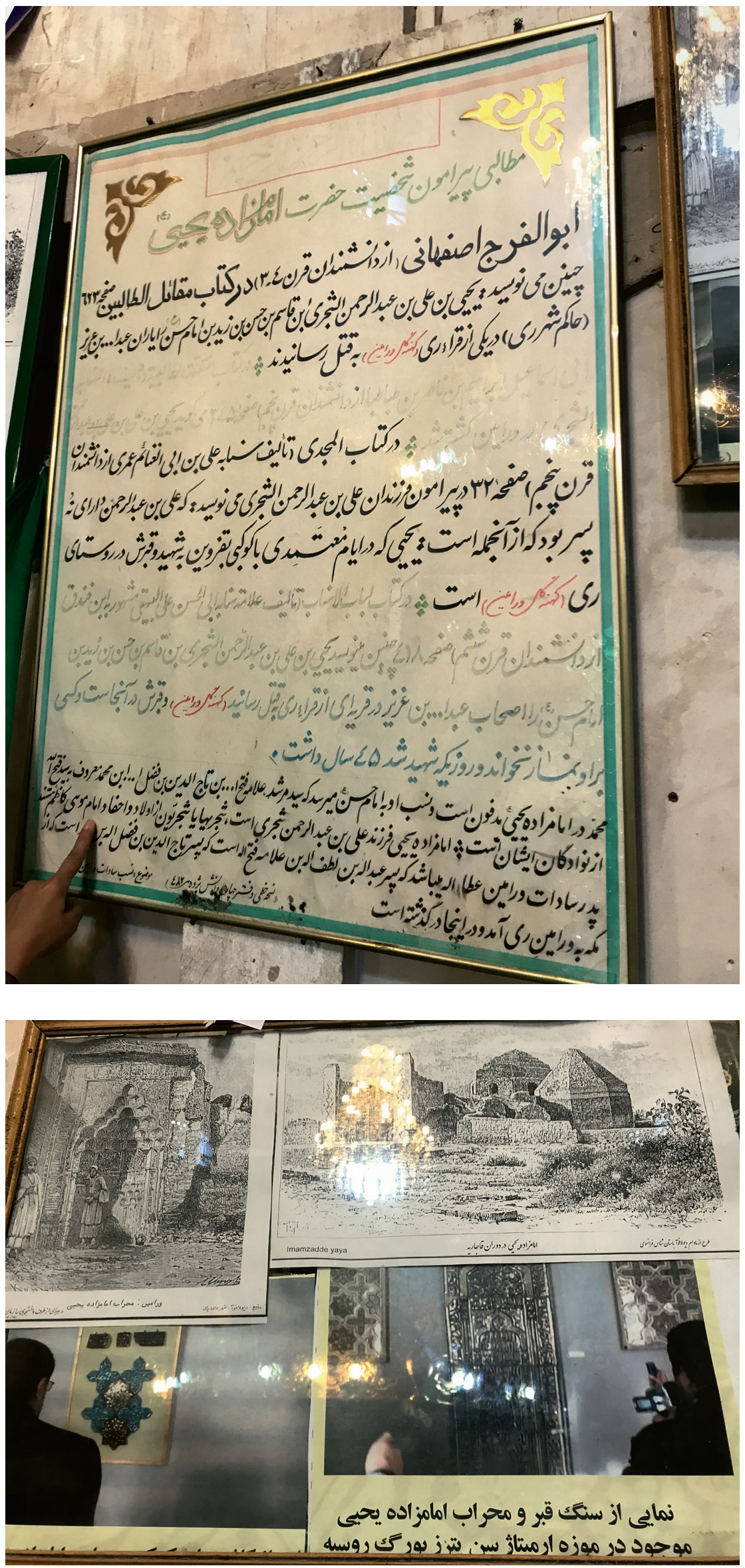

FIGURE 16

Genealogy of Emamzadeh Yahya, mounted in the center of the mihrab void (see fig. 14)

PHOTO: KEELAN OVERTON, 2018
FIGURE 17

Framed collage of images repeated on both sides of the mihrab void. Visible are the two woodcuts published in Jane Dieulafoy's $L a$ Perse (1887) and photographs taken of the tomb's tiles on display in the State Hermitage Museum in St. Petersburg, including the top panel of the cenotaph dated 10 Muharram 705/August 2, 1305 PHOTO: KEELAN OVERTON, 2018 
FIGURE 18

Lower wall to the immediate left of the mihrab void. The stucco inscription continues down the left side and then caps the dado, which was once decorated with star and cross luster tiles dated to the early 66os/126os. Visible today are replacement luster tiles from the late-nineteenth-century Qajar period

PHOTO: KEELAN OVERTON, 2018

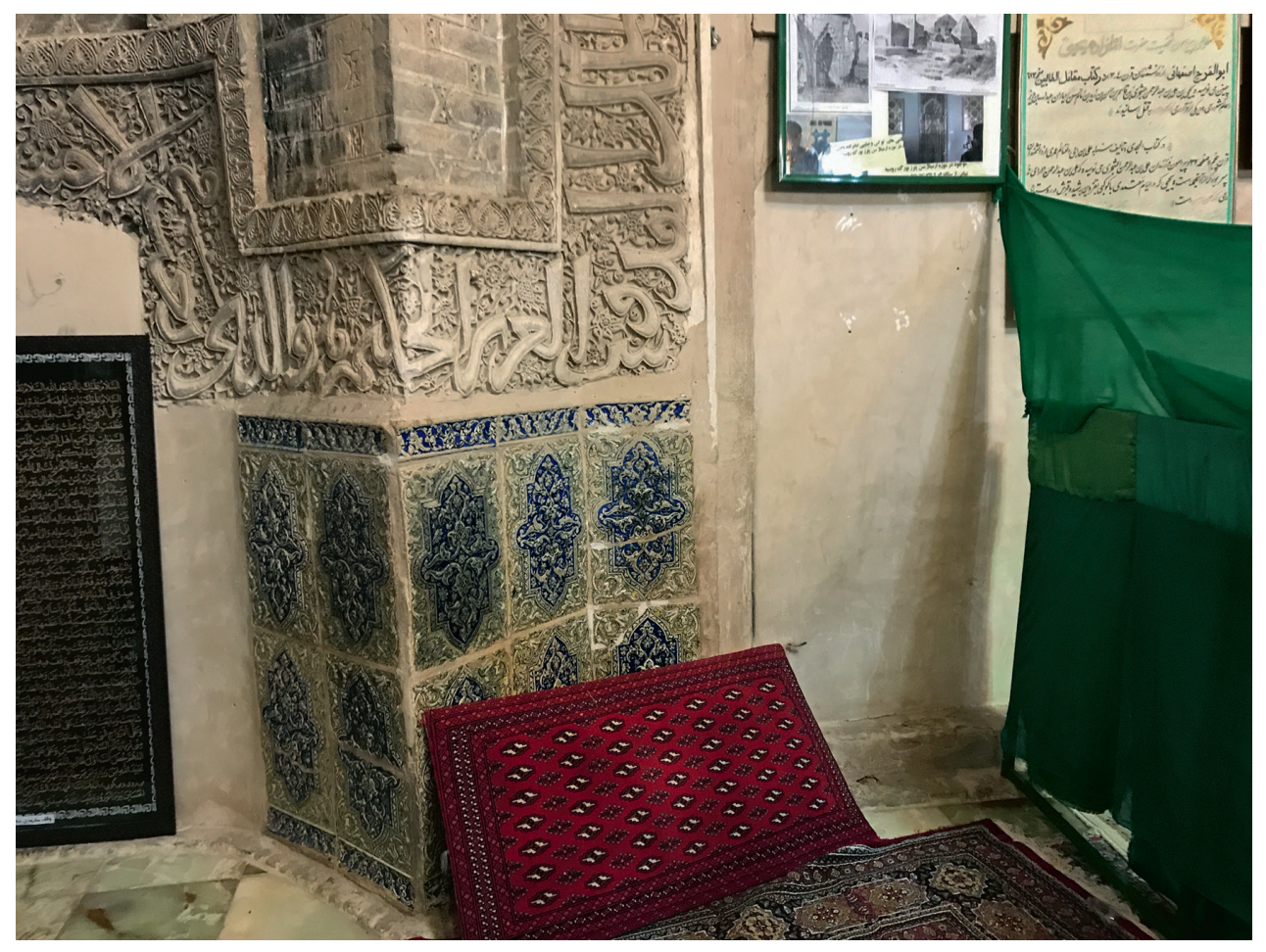

All together, the level of active response in the mihrab void at Varamin was provocative and unexpected, especially in comparison to the bare cadaver at Natanz (provocative on a different level). In the Emamzadeh Yahya, the ghost has been filled in a way that is simultaneously practical (qibla signs), historical (Dieulafoy prints), commemorative (cross fragment, Hermitage photographs), and spiritual (Emamzadeh Yahya's genealogy). ${ }^{51}$ The memory of the luster tiles is anything but forgotten, and it was interesting to juxtapose the amount of information volunteered by the tomb's "curators" versus the generally sparse labels accompanying the museumified tiles (fig. 1). Whereas the tomb has taken some steps to acknowledge the missing tiles (an elephant in the room), the museum rarely provides substantive information on the shrine (an abstract source). As we shall see (" 2019 "), the mihrab void is a mutable space that is curated according to the Islamic calendar. It remains to trace its appearance and evolution over the last century, and that of the site in general. ${ }^{52}$

At the height of about four feet, the stucco inscription running down the left side of the mihrab void makes a sharp turn to run horizontally above the dado (fig. 18). Here, and in other select areas of the dado, nineteenth-century rectangular tiles mask the voids left behind by the Ilkhanid stars and crosses (fig. 19). Although it is known that Qajar potters attempted faithful copies of Ilkhanid luster prototypes, both to fill the gaps of stripped tiles (hence historic restoration) and to sell as authentic (hence deception on the art market), imitation was not the goal here. ${ }^{53}$ Molded and underglaze painted in dark blue, black, and white on a pale yellow background, these Qajar replacements could never be confused as Ilkhanid, despite their fine execution. Two rectangular tiles are stacked vertically, each has a dark blue border with a central trefoil flanked by single leaves, and together they frame the upper and lower edges of the dado. In the corner niches of the qibla wall, the stucco epigraphic band juts up by about a foot (figs. 12-13), and smaller tiles would have filled these spaces. The current piecemeal state of this Qajar revetment raises questions. Either it was never completed or represents a second and more recent round of illicit removal. ${ }^{54}$ 


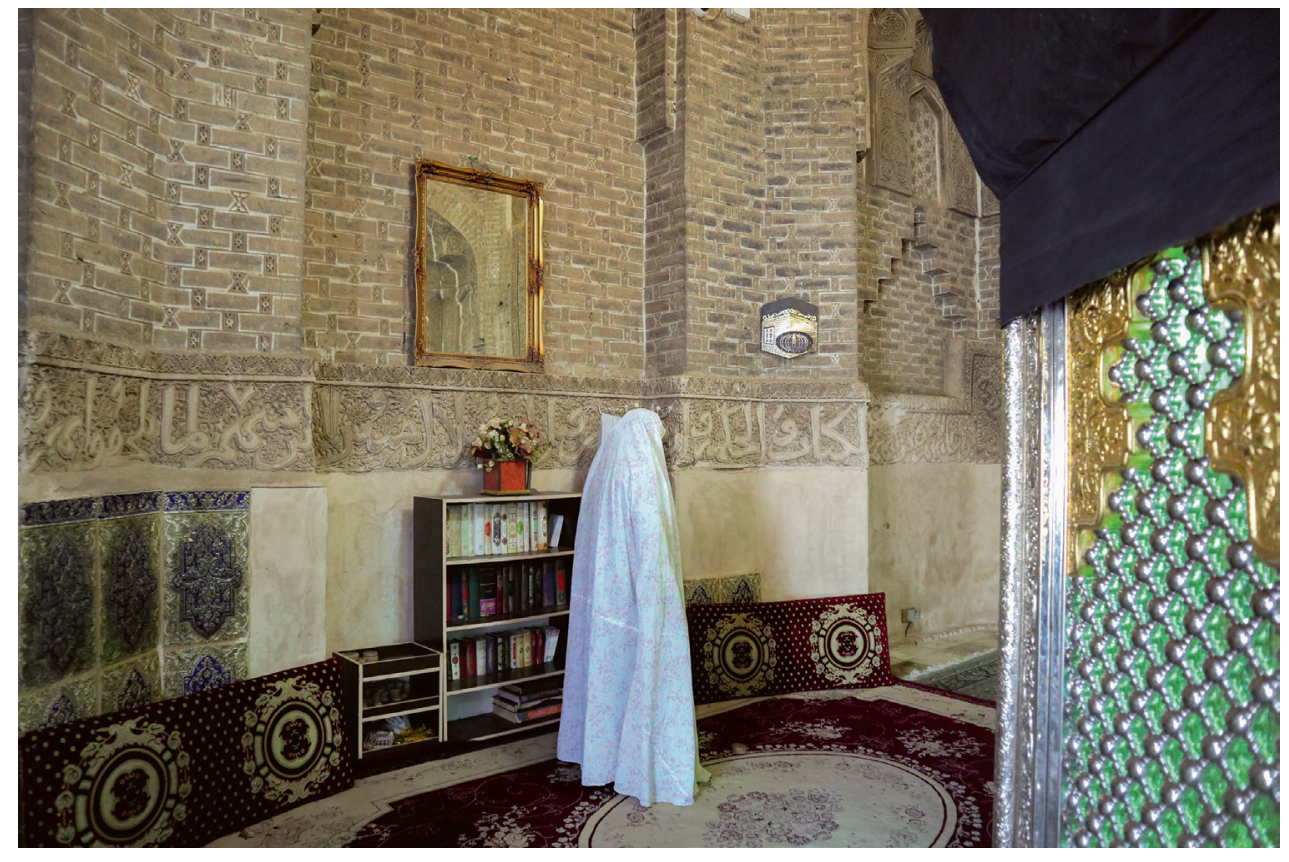

Save for select areas of loss, disruptions to its borders, and possible overcleaning, the stucco epigraphic band is in excellent condition and prominently displays the date (west wall) before transitioning to the hadith that ultimately climbs up the right side of the mihrab (fig. 14). ${ }^{55}$ It remains to assess the formal relationship between this impressive stucco band, whose bold letters sit upon a delicate background of diverse floral designs, and the luster mihrab once nested within it. Another area of research concerns the miniature inscriptions written in black in a professional hand (possibly naskh) on some of the large letters of the stucco band. A prayer opening with ilāhì bi-hurmatīhi is partially visible on the mim of muharram and attests another level of active response to the space. ${ }^{56}$

A few days after my initial visit to Varamin, I returned with the tour group from the Asian Art Museum. We began at the congregational mosque, where an official from the Varamin branch of the Department of Cultural Heritage (Sāzmān-e Mìrās-e Farhangī; Mìrās for short) met the group and proceeded to accompany us to the Emamzadeh Yahya and tower of 'Ala' al-Din. ${ }^{57}$ The visit to the emāmzādeh was a success, at least from the perspective of travelers interested in less touristic sites, and included a lively discussion about the displaced tilework with the shrine's caretakers. Where and how would it ideally be preserved? Who can take the best care of it? Is the mihrab a sacred object, functional architectural element, work of art, or all of the above?58

It remains to be seen if the Emamzadeh Yahya will ever become a more common destination on the cultural and/or foreign tourist map, but perhaps the more pressing questions are: Should it be, and who should decide? In spite of its looted tilework, the Emamzadeh Yahya is anything but a "naked tomb shrine" but rather a vibrant site of local piety, pride, agency, and beauty. Some would argue that it is best left alone. The world has consumed enough with the aestheticized and commodified tiles, and nonreligious foreign tourism would have a detrimental impact on the sacred space. Others might like to see the tomb added to the city's existing tourist circuit, inclusive of the congregational mosque and tower of 'Ala' al-Din, as this could contribute to the local economy. Still others might prefer a compromise, as long as it has a positive impact on the shrine, neighborhood, and city. As a historian who has studied the impact of tourism on the making and breaking of Iran's architectural heritage in past centuries, it
FIGURE 19

Stucco inscription wrapping the east side (women's) of the tomb at eye level. The dado below is mostly blank, save for a few Qajar-period replacement tiles PHOTO: KIMIA MALEKI, 2019 
was fascinating to observe comparable dynamics playing out in the present, especially when our tour group was asked to pose for photographs at the end of the visit. My participation was not without hesitation, however, given the local and intimate nature of the site and the many voices competing for its future.

In his well-known speech delivered in Tehran in April 1925, shortly after he had become an advisory curator of "Muhammadan" (today Islamic) art at the Art Institute of Chicago, Arthur Upham Pope singled out Varamin's congregational mosque (Masjid-e Jameh) for praise. ${ }^{59}$ In 1976, on the fiftieth anniversary of the advent of the Pahlavi dynasty (192579), Pope's lecture was translated into Persian, published as a book with an introduction by Isa Sadiq, and distributed throughout schools in Iran as a didactic tool. ${ }^{60}$ During my high school years in Tehran, the Varamin mosque was a staple of the college entrance exam and a curriculum rooted in style. As for the study of zarrinfäm (luster), the curriculum focused on Kashan, the center of production.

Ironically, it was only when I left Iran that I first learned about the Emamzadeh Yahya at Varamin. At the Art Institute of Chicago, where I helped to curate the Islamic galleries between 2016-19, I encountered the museum's star and cross tiles from the shrine (fig. 1). ${ }^{61}$ It felt a bit sad and strange to learn about the site through its tiles in an American museum and books in the library, versus Iran itself. Because of travel limitations imposed on Iranians living in the United States, a visit to Varamin was unlikely, but I hoped that I might be able to see the mihrab in Honolulu. Thinking about the transfer of the mihrab from Varamin to Honolulu was a complex and emotional process, given its decontextualization and secularization in an American woman's home in the middle of the Pacific. ${ }^{62}$ The star and cross tiles in Chicago sustained my interest in the emāmzādeh, and when I returned to Iran in 2019, I was able to visit it for the first time.

In Muharram/October 2019, Waze, the most popular navigational application available on cell phones in Iran, guided me by car from the 'Ala' al-Din tower in the center of Varamin to the Emamzadeh Yahya to the immediate south. Instead of taking me to the main entrance on the north (fig. 5), the app led me to the back of the complex through narrow alleyways filled with the smells of traditional dishes being cooked on Friday. As I entered the complex through the south gate (\#2 in fig. 4), I felt like I was in a private area reserved for neighborhood locals. The peaceful courtyard contains graves and tombs of locals from the medieval period to the present day, including martyrs (sing. shahid) of the Iran-Iraq war. The site is regulated by the Departments of Endowments and Charity Affairs (Sāzmān-e Awqā f va Omūr-e Khayrīya) and Cultural Heritage (Mīrāss), and permission for burial is generally restricted to those ones who have stipulated this request in their will (vașīyyat-nāmeh) ${ }^{63}$

Of the around forty-five emāmzādehs in Varamin county, the Emamzadeh Yahya is among the most important. In recent years, the shrine has been the focus of renovation (marremat va bāzs $\bar{a} z \bar{\imath})$ focused on fixing cracks (terak) resulting from earlier improper restoration. ${ }^{64}$ The shrine's surroundings have also been improved, a phenomenon known as beh-sāzì (lit. to make better) or mohavvațeh sāzì (mohavvațeh meaning "surrounding" or "enclosure"). The northern entrance gate (see "2018") is one such improvement, as are sidewalks, paved roads, and landscaping. The courtyard of the complex has also been enhanced with the planting of trees and flowers and the addition of benches, lights, and water fountains. These external and internal improvements have made the Emamzadeh Yahya popular not only as a sacred emāmzādeh, but also as a park-like space where locals, especially women, gather for picnics and visit the graves of their loved 
ones. Many Iranian urban shrines are undergoing such transformations into welcoming social spaces, but processes of "improvement" often introduce modern materials that are at odds with the original aesthetic and/or directly threaten the historical fabric. ${ }^{65}$

Balancing the historical integrity of the Emamzadeh Yahya with the desires of the local community and the demands of urban infrastructure is an ongoing challenge. In June 2019, the digging of a well by the municipality just outside of the shrine's perimeter wall resulted in the discovery of several Sassanian (224-651) and possibly Seljuk pottery vessels. ${ }^{66}$ The digging was immediately stopped and an archaeologist was called to the site. It remains to be seen if the Emamzadeh Yahya and its environs will be the focus of future archaeological excavation. The many graves in the courtyard pose obvious challenges.

Over the last five years, Varamin officials have attempted to increase local awareness of the Emamzadeh Yahya's historical significance. Ironically, one common method of legitimizing the site among Iranian audiences has been to cite the presence of its stolen luster tiles in foreign museums, especially the Hermitage and V\&A. ${ }^{67}$ In August 2015, the emāmzādeh was promoted as the religious center of Varamin and became the site for Arbaeen (Arbaeen means "forty" and refers to the fortieth day after Ashura, when Shi'a pilgrims gather at the tomb of Imam Hossein at Karbala and major commemorations are held elsewhere). Authorities also recognized that in addition to being an important destination for "religious tourism" (gardeshgarī-e mazhabì), the emāmzādeh had the potential to become a larger "tourism hub" (qūtb-e gardeshgarī) and center for Islamic learning. ${ }^{68}$ The welcoming of the tour group from the Asian Art Museum (see "2018") seems to attest efforts to expand the site's touristic reach.

Among Shi'a believers, Emamzadeh Yahya's personality (shakhșiat) continues to resonate, and his tomb is considered mojarrab (lit. experienced, tested, or tried out), meaning that prayers performed there are believed to yield positive results. Since the pilgrim's wishes are expected to be fulfilled, the shrine has attracted a significant following, including among Afghan immigrants. According to a 2017 news source, approximately 120,000 Afghans live in Varamin. ${ }^{69}$ The city's proximity to Tehran has contributed to this influx of immigrants, and Afghans play a key role in construction and farming. The practice of visitation to emāmzädehs is shared between Iranians and Afghans, and this reality contributes to the diversity of such sites in Varamin.

In early December 2018, a group of Varamin locals noticed that one of the historical marble tombstones installed on the right side of the tomb's façade had gone missing. The news outlet Eskān reported the disappearance in a punchy piece that commented on the shrine's plundering ( $t \bar{a} r \bar{a} j$ or $q \bar{a} r a t$ ) and criticized heritage officials for failing to secure its protection..$^{70}$ Images of the tombstone in place and missing were included in the exposé, as were those of tiles now in the V\&A and Walters Art Museum. ${ }^{71}$ That same evening, as reported in Mehr News Agency, the Varamin Mìrās held a press conference in which the temporary director clarified that the "disappeared" tombstone had in fact been transferred to the inside of the tomb during recent restoration (fig. 20 ; also see the background of fig. 13) ${ }^{72}$ The director concluded by thanking the shrine's board of trustees and appeasing local concerns: "There are strong security measures, like surveillance cameras, in the historical centers of Varamin, especially at the Emamzadeh Yahya" (see the camera on the top of the gate in fig. 5). This incident further demonstrates the local community's awareness of the site's looting in the past and concern with its protection in the present. It also reiterates the fact that "local voices" must distinguish between neighborhood residents who go to the site for ziy $\bar{a}$ rat and gravesite visitation and heritage authorities responsible for its security and preservation.

During my visit, I realized that local protection of the shrine was not confined to the removal of historical elements. As I was about to take pictures inside the tomb, several

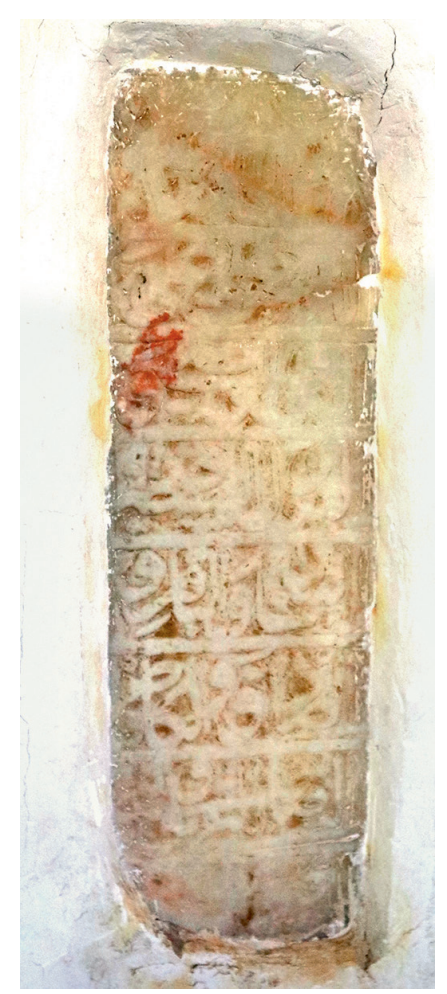

FIGURE 20

Marble tombstone mounted in the southwest corner niche of the tomb (fig. 13), transferred there from the exterior façade PHOTO: KIMIA MALEKI, 2019 


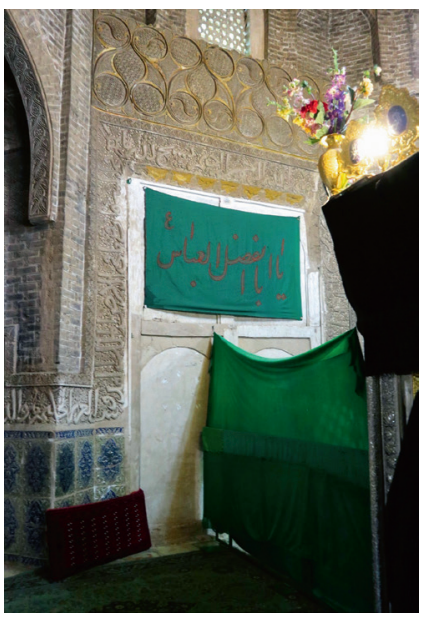

FIGURE 21

Mihrab void as decorated during Muharram. The genealogy and didactics have been removed (compare to fig. 14) and replaced with a banner in praise of 'Abbas b. 'Ali

PHOTO: KIMIA MALEKI, 2019 residents who had come to the site for Friday prayers asked me for my official permission from the Mìrās to take pictures (I had already confirmed that I did not need a special permission, except if I intended to use a drone). This sensitivity to the purpose of my visit again illustrates local caution toward visitors and wariness about theft. It is clear that the plunder of the luster tilework in the late nineteenth century continues to impact the site. It has also informed the administration's approach to the crypt (known locally as the sardāb or ganjīneh, lit. treasury), which has never been opened to the public. At present (February 2020), the Mìrās is considering opening the crypt to visitors, but they will need to guarantee its safety and appease local concerns. ${ }^{73}$

Since I visited the Emamzadeh Yahya during Muharram, its appearance and function had shifted to accommodate the holiday. The site's sanctity was no longer limited to Emamzadeh Yahya and the personal prayers and rituals undertaken in the tomb proper, but now also focused on the third Imam, Hossein b. 'Ali (d. 68o), and the mourning

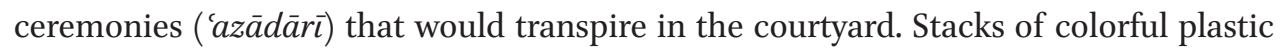
chairs hinted at crowds and events to come, including processions of men performing rhythmic chest beating (sineh zanī) and self-flagellation (zanjīr zanī) before proceeding to other nearby emāmzādehs. The façade of the tomb was now covered in black, green, and red banners and textiles to commemorate Muharram (figs. 7-8), and the inside of the tomb had also taken on a different appearance. The mihrab space was no longer decorated with Emamzadeh Yahya's genealogy and didactics about the luster tilework (figs. 14-17), but instead cloaked in a green banner with an invocation to 'Abbas b. 'Ali (Abu l-Fazl al-'Abbas; d. 680), also martyred at Karbala (fig. 21). The upper portion of the zarịh was also covered in black, obscuring the inscriptions and lending a somber air (fig. 13). These differences underscore the fact that the emāmzādeh's appearance and function vary according to the events of the Islamic calendar.

The Emamzadeh Yahya is a rich monument of Ilkhanid art and architecture, but it is also a space of daily devotion between locals and the holy person entombed within. Over the centuries, the Shi'a residents of Varamin have endowed gifts of various kinds in the hopes of having their wishes and requests fulfilled by Emamzadeh Yahya. During the Ilkhanid period, this endowment took the form of lavish luster tiles and stuccowork. Today, residents continue to care for the site in many ways, including safeguarding its historical elements and holding heritage officials accountable. The shrine's continued activation - its "livingness" - rests in the direct relationship between Emamzadeh Yahya, the local populace, and the architectural complex as a whole.

Iran has been tremendously impacted by the global pandemic coviD-19 (coronavirus disease 2019) and continues to adapt to the "new normal." ${ }^{44}$ As we have seen, zì $\bar{a}$ rat is a tactile experience rooted in the touching of communal furnishings and objects (doors, $\dot{z}$ arĭhs, chadors, mohr, carpets, sacred texts), and the circumambulation of the żarih can be a crowded experience. As potential "hot spots" for the spread of the virus, shrines and emāmzädehs have modified visitation in accordance with social distancing and heightened sanitation. This is not the first time that Iranian shrines have had to adapt to a pandemic. During the nineteenth century, the great plague (1830-1) and frequent outbreaks of cholera forced the closure of its largest shrines. ${ }^{75}$

During the early days of the coronavirus outbreak (February 2020), Iranian authorities elected to keep the country's shrines open. Videos of men licking żarĭhs in defiance went viral, the number of infected pilgrims began to grow, and the government was soon forced to consider closures. ${ }^{76}$ In mid-March, after about a month of tussling, it 
closed the shrines of Imam Reza in Mashhad, Fatima Masumeh in Qom, and Shah Abdol-Azim in Rey. The closure of these major sites of pilgrimage generated protests among segments of the population that viewed this act as sacrilegious, and one response to the controversy was to convert some shrines, including Shah Cheragh in Shiraz, into workshops for making masks. ${ }^{77}$ By April, the Awqã $f$ emphasized that despite being closed to $z \bar{y} \bar{a}$ rat, the buildings and facilities of shrines were still being used for the greater good, including cooking meals for the poor $(n a z r r \bar{\imath})$, holding virtual religious events, and housing makeshift medical stations. ${ }^{78}$

In advance of Nowruz (the Persian New Year holiday), the Varamin Mìrās and Awqā f announced the closure of a total of eight emāmzādehs in Varamin and nearby Qarchak, including the Emamzadeh Yahya. ${ }^{79}$ This decision was made before the last day of the year (29 Esfand $1398 \mathrm{sh} /$ March 19, 2020), when families typically visit the graves of their loved ones and recite the Fatiha, give away snacks in memory of their relatives (khayrāt, or charity), and pray for their blessings. Residents were warned that the Varamin emāmzādehs would be closed in their entirety, and this was distressing to those who spend the moment of the spring equinox at the graves of their loved ones. This circumstance again underscores the Emamzadeh Yahya's function as a living complex, not just a medieval tomb, and the importance of its courtyard cemetery as a space of communal gathering and remembrance.

The impact of CoviD-19 continued into Ramadan/May 2020. All mosques and shrines remained closed, and families were advised not to gather for the breaking of the fast (īftār), a practice of upmost importance during this holy month. Alongside state media, local religious organizations (hay'ats) began to transfer live prayer sessions and lectures to online platforms. By the time of Muharram/August 2020, the holding of virtual events had become a "new normal" on Instagram, Telegram, Aparat (the Iranian domestic version of YouTube), and Filimo (the Iranian domestic version of Netflix). ${ }^{80}$

One of the most important rituals of Muharram is to gather in hosseinīyeh, spaces dedicated to mourning Imam Hossein and remembering the events of Karbala, especially through sad songs (dirges) known as rowzeh. For Muharram 2020, the hay'ats developed alternative methods for transmitting the physical hosseiniyeh into the households of ordinary Iranians. Each evening, famous maddāhs (singers, eulogists) perform rowzeh in the alleyways, streets, and schools of different neighborhoods. These "mobile hosseiniyehs" are effectively pop-up events and can be heard by residents from the comfort of their own homes or watched live on Instagram and Aparat, usually with the hashtag \#har_kücheh_yek_hosseinīyeh (\#each alley, one hosseinīyeh). ${ }^{81}$ At the beginning of the outbreak, some maddāhs disputed the cancellation of events, largely because their careers and incomes hinge on the first ten days of Muharram. They received backlash on social media for not being sensitive to the risks of large events and soon became more cooperative. Negotiations between the Ministry of Health and Medical Education and local hay'ats (representatives of the maddāhs) ultimately led to a compromise and the holding of virtual events. ${ }^{82}$

A few larger emāmzādehs, such as the Emamzadeh Saleh near Tajrish Square in Tehran, have been granted permission to hold live events with smaller numbers. Photographs and films of recent maddāhī (performances by the maddāhn) capture an entirely different type of communal ritual. Instead of dense crowds standing shoulder to shoulder and performing rhythmic chest beating, chanting, and crying in response to the maddāh, mourners now sit and stand in designated areas separated by at least six feet. ${ }^{83}$ This degree of crowd control, organization, and relative stillness is unprecedented in the history of Muharram ceremonies in Iran, which are typically frenetic and fluid events, and suggests that protocols set by the National Committee to Combat Corona (Setād-e melli-e moqābeleh bā Koronā) are being followed. Also noticeably absent in this 
year's commemorations are the physical progressions of mourners throughout the city and the communal sharing of food (nazrī).

In August 2020, the Emamzadeh Yahya reopened for limited attendance, but large gatherings remain prohibited. On a Friday afternoon in late September, anthropologist Alex Shams observed a few women praying in the courtyard and inside the tomb; in short, a relatively normal day at the shrine. As for Arbaeen (October 8), most large events and processions were canceled, and Iran is now experiencing a tragic "third wave" of the pandemic. As Iranian religious sites continue to meet the vast challenges posed by COVID-19 and to modify their practices accordingly, we must wonder if museums that are the custodians of Iranian Shi'a material culture will also adjust to the times - specifically, to the ongoing uprisings against colonialist, imperialist, and problematic pasts around the world. ${ }^{84}$

It is no secret that much of the "Islamic art" on display in global museums exists in a fragmented and decontextualized state. Architectural furnishings have been plucked from buildings and stripped of original function, surface revetment of all kinds has been removed from original walls and broken up, illustrated folios once part of books now exist in solitary frames on the wall, and many objects remain fractions of their original selves, especially ceramic vessels and other archaeological finds. The field has long recognized the tearing up of manuscripts as one of the greatest crimes of the twentiethcentury art market, and the decontextualization of illustrated folios from their parent manuscripts is described with powerful terms like "divorce," "mutilation," and "dismemberment," and even emotional ones like "sad." 85 As argued by Christiane Gruber in an October 2019 op-ed, accountability for the ongoing destruction of manuscripts rests firmly in the mainstream. ${ }^{86}$ Gruber calls upon art professionals to "get ethical" and concludes that "works of art should not be treated like cadavers suitable for dissection."

When it comes to the architectural cadavers left behind from the removal of Iran's luster tilework, the crime is mainly (hopefully) one of the nineteenth-century past, and scholarship has long described this act as "plunder" and "looting," regardless of the precise legal statute in place or not. What remains a challenge and responsibility of the present is a more transparent accounting of such histories for general audiences and a consideration of how sites like the Emamzadeh Yahya have evolved in relation to and beyond the loss, and not just how the world has collected the beautiful gains. ${ }^{87}$ As we have seen, the plunder of the emāmzādeh's tilework approximately 150 years ago still looms large in the present consciousness of Varamin, but the site and its constituents continue to define and redefine its future, even re-appropriating its displaced tiles as a legitimizing force. Like many monuments torn between local, national, and global stakeholders, the Emamzadeh Yahya forces a consideration of difficult questions: Whose heritage is it anyway? And how can a stolen heritage be better shared? 88

In a June 2019 online essay considering how the teaching of "beautiful monuments" might engage with the vexed realities of the present, Kishwar Rizvi posed a serious of probing questions: "Can history be narrated in the present tense? What role does architecture have to play in teaching the past in a way that doesn't sanitize or obscure the present? ... How can one teach the history of a place or an architectural monument that is juxtaposed against the here and now? Is it possible to engage the field in a way that is academically rigorous and also self-reflective?"89 In the wake of controversies surrounding contested sites like the Hagia Sophia and Confederate monuments in the United States, these questions are increasingly pertinent, and the Emamzadeh Yahya 
affords fertile ground for testing such alternative methodologies. As we have seen, a present history of the shrine is critical to a reckoning of its nineteenth-century plunder and in turn a rounder understanding of its Ilkhanid aesthetic. Such a method need not be applied to all monuments of the canon, but is an important gesture for those that exist in fractured yet celebrated states in global museums and whose rupture continues to resonate at the sites themselves. As histories and narratives of all kinds face public calls for revision, we can expect the field of Islamic art to continue to confront its fraught past. ${ }^{90}$

From a museological perspective, the Emamzadeh Yahya offers ample opportunities for expansion and reevaluation. Whereas many luster tiles in museums will never be reunited with their original homes, which remain truly anonymous, those from the Emamzadeh Yahya can be matched to its walls, especially the distinct stars and crosses (fig. 1). ${ }^{91}$ As galleries of Islamic art continue to undergo renovation, it will be interesting to observe if and how the presentation of the Emamzadeh Yahya evolves over time. It is not reasonable to expect all museums with the shrine's tiles to tackle the question head on in the gallery, and curatorial interpretation can be limited by a range of factors, including the costs of exhibition design, low word counts on labels, and even more controversial collections. Nevertheless, the digital sphere and its associated technologies (museum websites, iPhone apps, interactive screens, holograms, $3 \mathrm{D}$ modeling, crowd sourcing) afford additional space for tackling complex narratives. We can generally observe that future scholarship on the Emamzadeh Yahya would benefit from an expansion of comparanda and voices, including contemporary sites with in situ tilework and Iran-based scholars, curators, heritage officials, and artists, which together would balance the prevailing emphasis on museum tiles and external perspectives. ${ }^{92}$ An additional level of dialogue would involve the local community of residents and caretakers. In the case of the "disappeared" marble tombstone (fig. 20) once on the façade of the tomb, one of our best sources for reading its surface is the photograph taken by a resident and published in a far from academic outlet. ${ }^{93}$

In recent years, the field of Islamic art history has by necessity become more vocal about at risk cultural heritage. ${ }^{94}$ The threats faced by the Emamzadeh Yahya remain both literal and conceptual: possible ongoing theft of historical elements, undocumented or problematic restoration, urban encroachment and "improvement," and the site's continued anonymity (to some) in the shadow of its tiles. ${ }^{95}$ The last lacunae can be resolved through a pedagogical balancing of the complex as a historical monument of the past, āstān-e moqaddas of the present, and cultural heritage site whose future remains to be determined. The Emamzadeh Yahya is not only a critical source for Ilkhanid history but also a test case for experimental museology and a gateway for exploring religiosity, preservation, and tourism of all kinds in today's Varamin. ${ }^{96}$ For architectural history in general, it raises critical questions about how we might better integrate local perspectives, unvarnished realities, continued use, and diachronic analysis within our academic narratives.

\section{Acknowledgments}

We have separated our text sections in order to communicate our individual experiences of the Emamzadeh Yahya. Overton has written the introduction, historiography, 2018 section, and conclusion. Maleki has written the 2019 and 2020 sections. We use uppercase Emamzadeh to refer to the entombed religious figure (Emamzadeh Yahya) and the site itself (the Emamzadeh Yahya) and lowercase emāmzādeh as a general reference to the complex and others of its kind. We are sincerely grateful to the anonymous 
reviewers for their comments and editor Stéphane Pradines for inclusion in this inaugural volume. Overton further thanks Mojgan Attarzadeh for assistance during her visits to the emāmzādeh; the shrine's caretakers and Mìrās officials for their hospitality; the Society for Asian Art for offering the 2018 tour; and Moya Carey, Heghnar Watenpaugh, and Peyvand Firouzeh for commenting on drafts.

\section{About the Authors}

Keelan Overton (PhD, UCLA, 2011) is a historian of art and architecture specializing in the eastern Islamic world from Iran to South Asia. Her recent publication is the edited volume Iran and the Deccan: Persianate Art, Culture, and Talent in Circulation, 1400-1700 (Indiana University Press, 2020), and her current book project is a global history of Persian tilework.

Kimia Maleki is a PhD student in the History of Art department at Johns Hopkins University. She received her MA from the School of the Art Institute of Chicago and her B.A. from the University of the Arts, Tehran. She is interested in historiography, archiving, and curatorial practice, especially as pertains to Iran.

\section{Bibliography}

Afkhami, Amir A. (2018). A Modern Contagion: Imperialism and Public Health in Iran's Age of Cholera. Baltimore: Johns Hopkins University Press.

Akbari, Abbas (2019). Kāshī va Kāshān. Kashan: Ceramic House Institute.

Akbari, Abbas (2019). Shāhkūreh. Kashan: Ceramic House Institute.

Allan, James W. (2011). The Art and Architecture of Twelver Shi'ism: Iraq, Iran and the Indian Sub-Continent. London: Azimuth.

Blair, Sheila S. (1986). The Ilkhanid Shrine Complex at Natanz, Iran. Cambridge: Center for Middle Easter Studies, Harvard University.

Blair, Sheila (2014). Art as Text: The Luster Mihrab in the Doris Duke Foundation for Islamic Art. In: Alireza Korangy and Daniel J. Sheffield, eds., No Tapping around Philology: A Festschrift in Honor of Wheeler McIntosh Thackston Jr.'s yoth Birthday. Wiesbaden: Harrassowitz Verlag, pp. 407-35.

Blair, Sheila (2015). Writing about faith: epigraphic evidence for the development of Twelver Shi 'ism in Iran. In: Fahmida Suleman, ed. People of the Prophet's House: Artistic and Ritual Expressions of Shi'i Islam. London: Azimuth Editions, pp. 102-10.

Blair, Sheila (2016). Architecture as a Source for Local History in the Mongol Period: The Example of Warāmīn. Journal of the Royal Asiatic Society 26 (1-2), pp. 215-28.

Blair, Sheila, and Jonathan Bloom (1994). The Art and Architecture of Islam, 1250-1800. New Haven: Yale University Press.

Carboni, Stefano, and Tomoko Masuya (1993). Persian Tiles. New York: Metropolitan Museum of Art.

Carey, Moya (2018). Persian Art: Collecting the Arts of Iran for the V\&A. London: Victoria and Albert Museum.

Christie's (2017). Art of the Islamic and Indian Worlds Including Oriental Rugs and Carpets. London: April 27.

Christie's (2000). Islamic. London: April 11.

Darieva, Tsypylma (2016). Prayer house or cultural centre? Restoring a mosque in post-socialist Armenia. Central Asian Survey 35 (2), pp. 292-308. 
Dieulafoy, Jane (1887). La Perse, la Chaldée et la Susiane: Relation de Voyage. Paris.

Ettinghausen, Richard, Oleg Grabar, and Marilyn Jenkins-Madina (2003). Islamic Art and Architecture, 650-1250. New Haven: Yale University Press.

Gluck, Jay, Noël Siver, and Sumi Hiramoto Gluck, eds. (1996). Surveyors of Persian art: a documentary biography of Arthur Upham Pope \& Phyllis Ackerman. Ashiya, Japan: SoPA; Costa Mesa, CA: Mazda Publishers.

Grbanovic, Ana Marija (2017). Some Remarks Regarding the Preservation of Ilkhanid Architectural Heritage in Iran: History, Challenges and Perspectives. In:Joaquim Rodrigues dos Santos, ed., Preserving Transcultural Heritage: Your Way or My Way?: Questions on Authenticity, Identity and Patrimonial Proceedings in the Safeguarding of Architectural Heritage Created in the Meeting of Cultures. Casal de Cambra: Caleidoscópio, pp. 799-81o.

Gruber, Christiane (2019). The collectors who cut up a masterpiece. Prospect Magazine, October 17, https://www.prospectmagazine.co.uk/arts-and-books/gruber-figure-frieze-folio -islamic-art-christies.

Haji-Qassemi, Kambiz, ed. (2010). Ganjnameh: Cyclopaedia of Iranian Islamic Architecture. Vol. 13. Emamzadehs and Mausoleums (Part III). Tehran: Shahid Beheshti University Press.

Hart, Fuchsia (2020). Contagion or Cure? A History of Healing and Pandemic in Qom, Ajam Media Collective, May 12, https://ajammc.com/2020/o5/12/healing-pandemic-qom/.

Ivanov, Anatol (2003). s.v. Hermitage Museum ii. Collection of the Islamic Period. Encyclopaedia Iranica, December 15, http://www.iranicaonline.org/articles/hermitage-museum-ii.

Kadoi, Yuka (2016). The Rise of Persian Art Connoisseurship: Arthur Upham Pope and Early Twentieth-Century Chicago. In: Yuka Kadoi, ed., Arthur Upham Pope and A New Survey. Leiden: Brill, pp. 235-66.

Kafili, Heshmat (1392 sh/2013). Meḥrābhā-ye zarrīnfām-e ḥaram-e muṭahhar dar mūzeh-ye markazī-ye āstān-e quds-e rażavī. Shamsa 5 (18), pp. 1-17.

Karimi, Pamela, and Nasser Rabat, eds. (2016). The Destruction of Cultural Heritage: From Napoléon to ISIs. The Aggregate Architectural History Collaborative, https://architecture.mit .edu/publication/destruction-cultural-heritage-napoléon-isis.

Khosronejad, Pedram (2012). Anthropology, Islam and sainthood. In: Pedram Khosronejad, ed., Saints and Their Pilgrims in Iran and Neighbouring Countries. Wantage: Sean Kingston Publishing, pp. 1-20.

Khosronejad, Pedram, ed. (2012). The Art and Material Culture of Iranian Shi'ism: Iconography and Religious Devotion in Shi' Islam. London: I. B. Tauris.

Lashkari, Arash, Hamid Khatib Shahidi, and Somaye Mohajer Vatan (2013). A Preliminary Report of Excavations at Aveh Plain, Islamic Period. Iranian Journal of Archaeological Studies 3, pp. 21-37.

Littlefield, Sharon (2002). Doris Duke's Shangri La. Honolulu: Honolulu Academy of Arts.

MacDonald, Sally (2005). Stolen or Shared: Ancient Egypt at the Petrie Museum. In: Jocelyn Hackforth-Jones and Mary Roberts, eds., Edges of Empire: Orientalism and Visual Culture. Malden, MA: Blackwell Publishing, pp. 162-8o.

Maleki, Kimia (2019). Reading Arthur Upham Pope in Tehran (and Chicago). Art Institute of Chicago, Collection Spotlight, September 5, https://www.artic.edu/articles/766/ reading-arthur-upham-pope-in-tehran-and-chicago.

Masuya, Tomoko (200o). Persian tiles on European walls: collecting Ilkhanid tiles in nineteenth century Europe. Ars Orientalis 30, pp. 39-54.

McClary, Richard (2018). Re-Contextualizing the Object: Using New Technologies to Reconstruct the Lost Interiors of Medieval Islamic Buildings. International Journal of Islamic Architecture 7 (2), pp. $263-83$.

Melikian, Souren (1996). Destroying a Treasure: The Sad Story of a Manuscript. New York Times, April 27, http://www.nytimes.com/1996/o4/27/style/27iht-lon.t_3.htm. 
Mellins, Thomas, and Donald Albrecht, eds (2012). Doris Duke's Shangri La: A House in Paradise: Architecture, Landscape and Islamic Art. New York: Skira Rizzoli.

Overton, Keelan (2016). Filming, Photographing and Purveying in 'the New Iran:' The Legacy of Stephen H. Nyman, ca. 1937-42. In: Arthur Upham Pope and A New Survey of Persian Art, ed. Yuka Kadoi. Leiden and Boston: Brill, pp. 327-70.

Overton, Keelan (2019). Building Biographies: The Fates and Fortunes of Iran's Monumental Mihrabs. Lecture presented at the Center for Middle East Studies, University of California, Santa Barbara, 28 Oct. 2019.

Overton, Keelan (2020). Medieval Persian Tilework between the Field and Museum. Lecture 2 in the module entitled A Global Historiography of Persian Architecture: The Making and Breaking of Iran's Cultural Heritage. Global Architectural History Teaching Collaborative (GAHTC), MIT School of Architecture and Planning and The Andrew W. Mellon Foundation.

Overton, Keelan (forthcoming). Iran Unglazed: A Local-Global History of Persian Tilework.

Pope, Arthur Upham, and 'Isa Sadiq(1976). The past and future of Persian art. Tehran:Madreseh-ye 'Alī-e Khadamat-e Jahāngardī va Etțelāāàt.

al-Quda'i, Muhammad b. Salamah (1985). Musnad al-Shahāb. Beirut: Mu’assasat al-Risalah.

Ritter, Markus (2015). 'Zībātarīn': Tārīkhcha-ye mehrāb-e zarrīnfām-e Kāshān (623/1226) va gerdāvarī-ye āsār-e honarī-ye İrān dar Orūpā ['The Most Beautiful': The History of the 623/1226 Lustre Mihrab from Kashan and Persian Art Collecting in Europe]. In: Abbas Akbari, ed., Nīyayyesh-e Sharqī [An Oriental Devotion]. Tehran, pp. 5-24, 28, 68-8o.

Ritter, Markus (2018). The Kashan Mihrab in Berlin: a Historiography of Persian Lustreware. In: Yuka Kadoi, ed., Persian Art: Image-Making in Eurasia. Edinburgh: Edinburgh University Press, pp. $157-78$.

Rizvi, Kishwar (2019). The Other Side of Paradise, or 'Islamic' Architectures of Containment and Erasure. Platform, June 24, https://www.platformspace.net/home/the-other-side-of -paradise-or-islamic-architectures-of-containment-and-erasure.

Shams, Alex (2019). A Jewish Shrine inside a Mosque: the History of Ezekiel's Tomb in Iraq. Ajam Media Collective, March 3, https://ajammc.com/2019/o3/o3/ezekiels-tomb-jewish-iraqmuslim/.

Taqavi Nejad, Bahare, and Sediqe Mirsalehian (2015). Ārāyehhā-ye Gachborī-ye Boq'ehye Emāmzādeh Yaḥyā Varāmīn [Stuccowork of the Emamzadeh Yahya Varamin]. In: Emāmzādigān Tajallīgāh-e honar-e qodsī: barrasīe tāz'⿳亠̄ynat va ārāyehhā dar boqā'-e motebarekeh. Isfahan: Sāzmān-e Awqāf va Omūr-e Khayrīya.

Varjavand, Parviz (1998). s.v. Emāmzāda III. Number, distribution, and important examples. Encyclopaedia Iranica, December 15, http://www.iranicaonline.org/articles/emamzada-iii.

Vincent Robinson Galleries (1913). Exhibition of Persian art \& curios. The collection formed by J.R. Preece, Esq., C.M.G., Late H.B.M.'s Consul General at Ispahan, Persia. At the Vincent Robinson Galleries, 34, Wigmore Street, London, W. May, 1913. London: The Vincent Robinson Galleries.

Watenpaugh, Heghnar Zeitlian (2019). The Missing Pages: The Modern Life of a Medieval Manuscript, from Genocide to Justice. Stanford, CA: Stanford University Press.

Watson, Oliver (1975). The Masjid-i 'Alī, Quhrūd: An Architectural and Epigraphic Survey. Iran 13, pp. 59-74.

Watson, Oliver (1985). Persian Lustre Ware. London: Faber and Faber.

Wilber, Donald (1955). The Architecture of Islamic Iran: The Il Khänid Period. Princeton: Princeton University Press.

\section{News Reports \& Press Briefings (2016-20)}

Eskan News (1397 sh/2018). Emāmzādeh Yaḥyā beh zūdī nāpadīd mīshavad! Ghayb shodan-e nāgahānī sang-e qabr-e tārīkhī [Emamzadeh Yahya is going to disappear soon! The sudden disappearance of a historical tombstone]. 1 Azar/December 2, http://www.eskannews.com/ news $/ 15940 /$. 
Hamshahri Online (1399 sh/2020). Vazīr-e bedāsht dar jalaseh bā maddāhān darbāre-ye 'azādārī-e muḥarram-e emsāl che goft? [What did the health minister discuss with maddāḥs about the mourning sessions of this Muharram?], 8 Mordad/July 29, https://hamshahrionline .ir/x6z46.

Iran Front Page (2020). Iranian Holy Shrine Used for Production of Masks amid CovID-19 Outbreak. April 5, https://ifpnews.com/iranian-holy-shrine-used-for-production-of-masks -amid-covid-19-outbreak.

IRNA (Islamic Republic of Iran News Agency) (1395 sh/2017). Farmāndār: 120,00o mohājer-e Afghānestān dar Varāmīn zendegī mīkonand [Governor: 120,00o Afghan immigrants live in Varamin]. 1 Esfand/Feburary 19, www.irna.ir/news/82436734/.

IRNA (1397 sh/2018). 'Amalīyat-e bāzsāzī-ye Emāmzādeh Yaḥyā Varāmīn agāāz shod [The renovation of Emamzadeh Yahya in Varamin was launched]. 3 Azar/November 24, www.irna.ir/ news/83111197/.

IRNA (1398 sh/2020). Vorūd beh șahn-e hasht emāmzādeh dar Varāmīn va Qarchak mamnūc shod [Entrance has been forbidden to the courtyards of eight emāmzādehs in Varamin and Qarchak]. 27 Esfand/March 17, www.irna.ir/news/83718641/.

IRNA (1398 sh/2019). Kashf-e Sofālhāye dūreh-ye Sāsānī dar Varāmīn [Discovery of Sassanid pottery in Varamin]. 26 Khordad/June 16, www.irna.ir/news/83356288/.

ISNA (Iranian Students News Agency) (1399 sh/2020). Āyīn-e 'azādārī-e ḥosseinī dar emāmzādeh șāleh [Commemoration ritual in the Emamzadeh Saleh]. 3 Sharivar /August 24, https://www .isna.ir/photo/99060302127/.

Mehr News (1397 sh/2018). Enteqāl-e sang-e qabr-e Emāmzādeh Yahyā Varāmīn [Transfer of the tombstone of Emamzadeh Yahya]. 12 Azar/December 3, https://mehrnews.com/xN3tL.

Sāzmān-e Awqāf va Omūr-e Khayrīya (1399 sh/2020). Boqā'-ye motebarekeh tactịl nīst [The holy tombs are not closed]. 21 Farvardin/April 9, https://www.oghaf.ir/news/view-338879.aspx.

Sini, Rozina, and Armen Shahbazian (2020). Coronavirus: Iran Holy-Shrine-Lickers Face Prison. BBC News, March 3, https://www.bbc.com/news/blogs-trending-51706o21.

Varamin News Agency (1395 sh/2016). Emāmzādeh Yahyā nāshenākhteh mānd / āsārī keh beh mūzehāye orūpā resīd [Emamzadeh Yahya remained unknown / Objects that arrived in European museums]. 4 Azar/November 24, http://varaminma.ir/?p=59892.

\section{Notes}

1 Imamzada Yahya, Varamin, Archnet, https://archnet.org/sites/1684, italics added.

2 The most extensive assessment of the shrine's Ilkhanid history is Sheila Blair, Architecture as a Source for Local History in the Mongol Period: The Example of Warāmīn, Journal of the Royal Asiatic Society 26, 1-2 (2016), pp. 215-28. Alongside texts like Rashid al-Din's Jāmi` al-Tavārīkh, Blair examines Varamin's architectural heritage as a viable source for writing Ilkhanid history and in doing so balances centrist narratives with provincial ones.

3 I note "amateur anthropology" because we are not trained anthropologists, and none of our fieldwork qualifies as sustained participant-observation. In terms of method and tone, I have been inspired by Heghnar Zeitlian Watenpaugh, The Missing Pages: The Modern Life of a Medieval Manuscript, from Genocide to Justice (Stanford, CA: Stanford University Press, 2019); Alex Shams, A Jewish Shrine inside a Mosque: the History of Ezekiel's Tomb in Iraq, Ajam Media Collective, March 3, 2019, https://ajammc. com/2019/o3/o3/ezekiels-tomb-jewish-iraq-muslim/; and Tsypylma Darieva, Prayer house or cultural centre? Restoring a mosque in post-socialist Armenia, Central Asian Survey 35, 2 (2016), pp. 292-308.

4 Kambiz Haji-Qassemi, ed., Ganjnameh: Cyclopaedia of Iranian Islamic Architecture. Vol. 13. Emamzadehs and Mausoleums (Part III) (Tehran: Shahid Beheshti University Press, 2010), p. 82. Also see the list of notable emāmzādehs in Parviz Varjavand, s.v. Emāmzāda iii. Number, distribution, and important examples, Encyclopaedia Iranica, December 15, 1998 (updated December 13, 2011), http://www.iranicaonline. org/articles/emamzada-iii.

5 Jane Dieulafoy, La Perse, la Chaldée et la Susiane: Relation de Voyage (Paris, 1887), p. 147. Dieulafoy notes that the first stage of the complex included a twelfth-century Seljuk mosque, inclusive of an earlier Ghaznavid pavilion (pp. 148-9). 
Donald Wilber, The Architecture of Islamic Iran: The Il Khānid Period (Princeton: Princeton University Press, 1955), fig. 6 (cat. no. 11). Wilber describes his plan as "an attempt ... to suggest the ground plan of the shrine area at that time" (p. 109).

7 See the various plans and elevations in Haji-Qassemi, ed., Emamzadehs and Mausoleums, pp. 83-6.

8 Blair, Architecture as a Source, pp. 221-3.

9 Hadith identified and translated by Kimia Maleki and Sarah Aziz. See also Muhammad b. Salamah al-Quda'i, Musnad al-Shahāb (Beirut: Mu'assasat al-Risalah, 1985), p. 296, which includes some slight differences, including "I" instead of "Allah." For a transcription of the historical component of the inscription, see Blair, Architecture as a Source, p. 220.

Blair, Architecture as a Source, pp. 224-7.

11 Ibid, p. 227.

12 Oliver Watson, Persian Lustre Ware (London: Faber and Faber, 1985), no. 27, p. 191. While the majority of these examples are "complete" 8-pointed stars and 4-pointed crosses, the tiles located at the top and bottom of the dado would have had flat edges. Additional shapes may have also been required for portions of the dado that are slightly taller in the southwest and southeast corner niches.

13 I have identified probable Emamzadeh Yahya tiles in one Tehran collection. This research is ongoing and pending publication in my monograph entitled Iran Unglazed: A Local-Global History of Persian Tilework.

14 Doris Duke Foundation for Islamic Art (DDFIA), Honolulu, 48.327. Since many images of the mihrab are available on the museum's website (www.shangrilahawaii.org) and Google Images, we do not reproduce it here. For a detailed discussion, see Sheila Blair, Art as Text: The Luster Mihrab in the Doris Duke Foundation for Islamic Art, in Tapping around Philology: A Festschrift in Honor of Wheeler McIntosh Thackston Jr's 7oth Birthday, ed. Alireza Korangy and Daniel J. Sheffield (Wiesbaden: Harrassowitz Verlag, 2014). Later in life, Doris Duke also acquired several star and cross tiles from the Emamzadeh Yahya (48.361).

15 State Hermitage Museum, St. Petersburg, ИР-1594, visible on the museum's website, https://www.her mitagemuseum.org (search "Veramin" in "Collections Online"). The Varamin tiles in the Hermitage almost 1,ooo pieces, but mostly fragments - are undergoing restoration and will be redisplayed in the renovated Iran gallery (thanks to Ada Adamova for updates).

16 For intact cenotaphs with luster revetment, see Sheila S. Blair, Writing about faith: epigraphic evidence for the development of Twelver Shi'ism in Iran, in People of the Prophet's House: Artistic and Ritual Expressions of Shii Islam, ed. Fahmida Suleman (London: Azimuth Editions, 2015), fig. 2 (of Fatima Masumeh at Qom) and Abbas Akbari, Kāshī va Kāshān (Kashan: Kashan Ceramic House, 2019), passim. (of Habib b. Musa at Kashan).

17 Tomoko Masuya, Persian tiles on European walls: collecting Ilkhanid tiles in nineteenth century Europe, Ars Orientalis 30 (2000), pp. 39-54. According to Haji-Qassemi, ed., Emamzadehs and Mausoleums, p. 82, "the emamzadeh also had a superb and precious entrance door that has also been stolen."

18 “... the Emamzadeh Yahya is one of the most interesting monuments in the country, but also the only one that is closed and guarded ... certain parts of its revetment have been stolen (dérobée) and sold in Tehran at elevated prices." Dieulafoy, La Perse, p. 147. At the time of her visit, entry was forbidden to Christians, but she was given an exception.

19 On the removal of the luster mihrab from Kashan's Maydan Mosque, Markus Ritter has concluded: "The dismembering of such a large panel of tilework could not have gone unnoticed in Kashan and must have been undertaken with some consent of those responsible for the mosque and its vaqf, the 'ulama and the mutavalli, or of authorities in the city." Markus Ritter, The Kashan Mihrab in Berlin: a Historiography of Persian Lustreware, in Persian Art: Image-Making in Eurasia, ed. Yuka Kadoi (Edinburgh: Edinburgh University Press, 2018), p. 16o.

20 The Qajar minister Mirza Hasan Ashtiani 'Mostawfi al-Mamalik' (d. 1932) is known to have brought the Emamzadeh Yahya mihrab to Paris for exhibition (Blair, Art as Text, 416). According to Hagop Kevorkian, this act resulted in the minister's disgrace under Muzaffar al-Din Shah (r. 1896-1907), who "would not forgive Mostofy until he solemnly undertook not to dispose of the secret monument." The mihrab remained in storage in Paris for the next 12 years until a leading mujtahid of the Constitutional Revolution authorized Mostawfi al-Mamalik to "dispose of the monument," resulting in its sale to Kevorkian. Letter from Hagop Kevorkian to Charles Lang Freer, August 25, 1913. I am sincerely grateful to Karen Winslow for sharing this letter as this article was in press; it will be further analyzed separately.

21 Moya Carey, Persian Art: Collecting the Arts of Iran for the V\&A (London:Victoria and Albert Museum, 2018), chapter 2, passim.

22 Ibid., p. 102. This shipment came from Richard in November 1875. It is unclear if it is the same one discussed by Masuya, Persian Tiles, p. 44, which included thirty-seven tiles "from the ruins of Verameen." 
23 Carey, Persian Art, p. 105.

24 V\&A, 1821,A,B,-1876. Quoted from ibid.

25 A survey of the six mihrabs is provided in Blair, Art as Text, Table 1, p. 409. The Kashan (Berlin) example graces the cover of Richard Ettinghausen, Oleg Grabar, and Marilyn Jenkins-Madina, Islamic Art and Architecture, 650-1250 (New Haven: Yale University Press, 2003, 2nd edition). Also see Ritter, The Kashan Mihrab, fig. 9.7.

26 Heshmat Kafili, Meḥrābhā-ye zarrīnfām-e ḥaram-e muṭahhar dar mūzeh-ye markazī-ye āstān-e quds-e rażavī, Shamsa 5,18 (1392 sh/2013). The two finest mihrabs were on the qibla wall of the tomb of Imam Reza, while a smaller third example was in an adjacent space. For additional photographs of the mihrabs in the tomb in the 193os, see Keelan Overton, Filming, Photographing and Purveying in 'the New Iran:' The Legacy of Stephen H. Nyman, ca. 1937-42, in Arthur Upham Pope and A New Survey of Persian Art, ed. Yuka Kadoi (Leiden and Boston: Brill, 2016), figs. 13.1-13.2.

27 Mihrab: Islamic Museum, Tehran, no. 3270; Watson, Persian Lusterware, no. 123, p. 196. For two of the mihrab's tiles now in the Metropolitan Museum of Art (40.181.5-6), see Masuya, Persian Tiles, 44; Stefano Carboni and Tomoko Masuya, Persian Tiles (New York: Metropolitan Museum of Art, 1993), no. 23 , p. 28.

28 For a partial reconstruction of the mihrabin the Natanz tomb, see Richard McClary, Re-Contextualizing the Object: Using New Technologies to Reconstruct the Lost Interiors of Medieval Islamic Buildings, International Journal of Islamic Architecture 7, 2 (2018), fig. 3. In this article, McClary proposes a hypothetical exhibition in which photographs and digital recreations would recreate the tomb's original aesthetic in a custom-made structure of the same size.

29 On Varamin (Honolulu), see Blair, Art as Text. On Natanz (dispersed), see McClary, Re-Contextualizing the Object; Carey, Persian Art, passim. On Kashan (Berlin), see Ritter, The Kashan Mihrab and his earlier 'Zībātarīn': Tārīkhcha-ye mehrāb-e zarrīnfām-e Kāshān (623/1226) va gerdāvarī-ye ās̄ār-e honarī-ye Īrān dar Orūpā (“'The Most Beautiful': The History of the 623/1226 Lustre Mihrab from Kashan and Persian Art Collecting in Europe"), in Nìyāyesh-e Sharqī (An Oriental Devotion), ed. Abbas Akbari (Tehran, 2015), pp. 5-24, 28, 68-8o.

30 Akbari, Nōyāyesh-e Sharqū, Kāshī va Kāshān, and Shāhkūreh (Kashan: Kashan Ceramic House 2019). I first learned of Akbari's work in Ritter, The Most Beautiful and The Kashan Mihrab, and I thank the artist for his hospitality in 2018 and continued exchanges. Images of his 2015 exhibition An Oriental Devotion are visible online at https://www.36ocities.net/image/aun-art-gallery -nov-2015-abbas-akbari-an-oriental-devotion-o2.

31 For example, Carey, Persian Art, fig. 106 (London, 1885); Vincent Robinson, Exhibition of Persian art \& curios. The collection formed by J.R. Preece, Esq., C.M.G., Late H.B.M.'s Consul General at Ispahan, Persia. At the Vincent Robinson Galleries, 34, Wigmore Street, London, W. May, 1913 (London: The Vincent Robinson Galleries), pl. 1, where a packed display includes over thirty framed "trophies." On the Preece collection, see Ritter, The Kashan Mihrab.

32 It must be noted that as Shangri La's curator in 2011-12, I also described the shrine in such abbreviated and abstract terms in a report written for the museum's website. See Keelan Overton, Collection Highlights: Tilework: Ilkhanid Iran, Doris Duke Foundation for Islamic Art, 2012, http://www.shan grilahawaii.org/Islamic-Art-Collection/Collection-Highlights/Tileworks/Ilkhanid-Iran/ (no longer online). At the time, I had not yet visited the site, which has a profound impact on one's knowledge and perspective (see my account in "2018").

33 http://collections.vam.ac.uk/item/O8959o/tile-panel-ali-ibn-muhammad/; Watson, Persian Lustre Ware, pl. K; Bahareh Taqavi Nejad and Sediqe Mirsalehian, Ārāyehhā-ye Gachborī-ye Boq`eh-ye Emāmzādeh Yahyā Varāmīn [Stuccowork of the Emamzadeh Yahya Varamin], in Imāmzādigān Tajallīgāh-e honar-e qudsī: barrasīe tāz'̄̄ynat va ārāyehhā dar boqā'-e motebarekeh (Isfahan: Sāzmān-e Awqāf va Omūr-e Khayrīya, 2015), p. 9. I am grateful to Ali Tavakoli Dinani for alerting me to this article and sharing a pdf.

34 Haji-Qassemi, ed., Emamzadehs and Mausoleums, pp. 82-7.

35 The Archnet photographs are by Sheila Blair and Jonathan Bloom (1984) and Marie-Thérèse Ullens de Schooten (1951-70); IтTO, https://www.itto.org/iran/city/Varamin/.

36 For example, Sheila Blair and Jonathan Bloom, The Art and Architecture of Islam, 1250-1800 (New Haven: Yale University Press, 1994), fig. 19 (Hermitage cenotaph panel; the shrine is discussed on p. 14).

37 Space constraints have necessitated the cutting of images of the rear of the complex and the neighborhood to the south. We were not able to enter the tomb's crypt or side rooms, so what is presented here is by no means comprehensive.

$3^{8}$ An analysis of Iran's historical and present tourist maps is forthcoming in Iran Unglazed. When discussing tourism in Iran, it is important to distinguish between religious tourism (gardeshgari-e $m a z h a b \bar{\imath})$, which involves pilgrimage (zīyārat) to shrines and emāmzādehs, and cultural tourism generally focused on history, art, and architecture. 


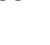

(a)

$$
\text { corot }
$$
originally painted.

$5^{6}$ We are grateful to Markus Ritter for redirecting our attention to these inscriptions, which are the focus of a separate research project at the University of Vienna. Much of the black writing on the letters of the date appears to have been deliberately scraped away.

57 During our previous visit, we had arranged for a local professor to meet the tour group. He ended up being unavailable and the Mìrās sent an official in his place. The offices of the Varamin Mìrās are on the grounds of the mosque. At the time of my visits, only the mosque and tomb tower had large Mìrās-sponsored bilingual (Persian and English) signs near the entrance describing the basics of the site.

$5^{8}$ Although these were compelling conversations, they were undoubtedly informed by language barriers and the fact that we were a foreign tour group accompanied by a Mirāa official. The shrine's caretakers are aware of the mihrab's location in Honolulu and volunteered a color printout of the 
"object." The repatriation of the mihrab did arise, but this is a complex issue that must be addressed elsewhere.

59 Speech entitled "The Past and Future of Persian Art," reprinted in Jay Gluck, Noël Siver, and Sumi Hiramoto Gluck, eds., Surveyors of Persian art: a documentary biography of Arthur Upham Pope \& Phyllis Ackerman (Ashiya, Japan: SoPA; Costa Mesa, CA: Mazda Publishers, 1996), p. 97. The event was held in the Tehran mansion formerly belonging to Sardar As'ad Bakhtiari (d. 1917), a key figure of the Constitutional Revolution. On Pope and Chicago, see Yuka Kadoi, The Rise of Persian Art Connoisseurship: Arthur Upham Pope and Early Twentieth-Century Chicago, in Arthur Upham Pope and A New Survey, ed. Kadoi, pp. 235-66.

6o Arthur Upham Pope and 'Isa Sadiq, The past and future of Persian art (Tehran: Madreseh-ye 'Alī-e Khadamat-e Jahāngardī va Ețtelāāāt, 1976). One of the few copies of this book in the United States is held at the Art Institute of Chicago. I used the copy at the National Library and Archives of Iran in Tehran.

61 Art Institute of Chicago, 1915.242 and 1915.243, also visible on the museum's website at https:// www.artic.edu/artworks/71231/star-shaped-tile and https://www.artic.edu/artworks/71227/ cross-shaped-tile.

62 I have expressed similar sentiments in my blog entitled "Reading Arthur Upham Pope in Tehran (and Chicago)," Art Institute of Chicago, Collection Spotlight, September 5, 2019, https://www.artic.edu/ articles/766/reading-arthur-upham-pope-in-tehran-and-chicago.

63 The Varamin area includes several other emāmzādehs that are common sites of burial, including the Emamzadeh Jaffar in Pishva to the east, which is a burial place for wealthier individuals. Phone call discussion between Kimia Maleki and Varamin Mīrās, February 2020.

64 IRNA, Amaliyāt-e bazsāzī-ye Emāmzādeh Yahyā Varāmīn ag̉āz shod [The renovation of Emamzadeh Yahya in Varamin was launched], 3 Azar 1397 sh/November 24, 2018, www.irna.ir/news/83111197/. The location of the cracks is unclear; perhaps the prominent ones in the squinches.

65 Conversation with Alex Shams, PhD candidate at the University of Chicago, who is writing his thesis on emāmzādehs in urban settings in Iran and Iraq.

66 IRNA, Kashf-e Sofālhāye dūreh-ye Sāsānī dar Varāmīn [Discovery of Sassanid pottery in Varamin], 26 Khordad 1398/June 16, 2019, www.irna.ir/news/83356288/.

67 Varamin News Agency, Emāmzādeh Yahyā nāshenākhteh mānd, āsārī keh beh mūzehāye orūpā resīd [Emamzadeh Yahya remained unknown/Objects that arrived in European museums], 4 Azar 1395/November 24, 2016, http://varaminma.ir/?p=59892. This article includes quotes from the city's interim Friday Imam and Mïrās and Awqāfofficials.

68 Ibid.

69 IRNA, Farmāndār:120,ooo mohājer-e Afghānestān darVarāmīn zendegī mīkonand [Governor: 120,000 Afghan immigrants live in Varamin], 1 Esfand 1395/Feburary 19, 2017, www.irna.ir/news/82436734/.

70 Eskan News, Emāmzādeh Yahyaa beh zūdī nāpadīd mīshavad! [Emamzadeh Yahya is going to disappear soon!]. Eskan is not a particularly well-known news outlet in Iran. It deals with urban and architectural news, but more credible outlets are known. This report does not meet conventional journalistic standards and is written in an informal and at times sarcastic manner. In spite of its less than neutral tone, it provides insight into the concerns of some Varamin residents.

71 V\&A star and cross panel, https://collections.vam.ac.uk/item/O8959o/tile-panel-ali-ibn-muhammad/; Walters Art Museum, 48.1292, https://art.thewalters.org/detail/19445/lusterware-cross-shaped-tile/.

72 Mehr News Agency, Enteqāl-e sang-e qabr-e Emāmzādeh Yahyā Varāmīn [Transfer of the tombstone of Emamzadeh Yahya], 12 Azar 1397 sh/December 3, 2018, https://www.mehrnews.com/ news $/ 4474177 /$. Mehr is one of the top news agencies in Iran. It covers broad issues and is an established, credible, and large organization. The tone of this report is far different from the Eskan example, and it opens by quoting the director's key statement: "This historical stone (sang-e tārīkhī) has been moved to inside the emāmzādeh during the recent restoration of the Emamzadeh Yahya Varamin." It also includes an image of the tombstone in its new interior home (see the background of fig. 13).

73 Phone call discussion between Kimia Maleki and Varamin Mīrās, February 2020.

74 Since the initial submission of this article in April 2020, Fuchsia Hart has written an excellent blog addressing some of the issues raised here. See Fuchsia Hart, Contagion or Cure? A History of Healing and Pandemic in Qom, Ajam Media Collective, May 12, 2020, https://ajammc.com/2020/05/12/ healing-pandemic-qom/. This article has been translated into Persian by Kimia Maleki for https:// anthropologyandculture.com.

75 Amir A. Afkhami, A Modern Contagion: Imperialism and Public Health in Iran's Age of Cholera (Baltimore: Johns Hopkins University Press, 2018).

76 Rozina Sini and Armen Shahbazian, Coronavirus: Iran Holy-Shrine-Lickers Face Prison, BBC News, March 3, 2020, https://www.bbc.com/news/blogs-trending-51706o21. 
Front Page, Iranian Holy Shrine Used for Production of Masks amid covID-19 Outbreak, April 5 2020, https://ifpnews.com/iranian-holy-shrine-used-for-production-of-masks-amid-covid-19outbreak

78 Sāzmān-e Awqāf va Omūr-e Khayrīya, Boqā'-ye motebarrekeh ta'țīl nīst [The holy tombs are not closed], 21 Farvardin 1399/April 9, 2020, https://www.oghaf.ir/news/view-338879.aspx. IRNA, Vorūd beh șahn-e hasht emāmzādeh dar Varāmīn va Qarchak mamnū' shod [Entrance has been forbidden to the courtyards of eight emāmzädehs in Varamin and Qarchak], 27 Esfand 1398/ March 17, 2020, www.irna.ir/news/83718641/.

8o The following webpage on Aparat is dedicated to all religious hay'ats throughout Iran that wish to live stream their sessions: https://www.aparat.com/moharam?itm_source=trend (Live Broadcasting of Religious Hay'ats [pakhsh-e zendeh-ye hay'atha-ye mazhabi]]).

81 This Mehr News video shows a maddāh performing at the doorstep of the family of a martyr (shahid) in Tehran: https://www.mehrnews.com/news/5006751.

82 Hamshahri Online, Vaz̄rr-e behdāsht dar jalaseh bā maddāhān darbāre-ye 'azādārīe muharram-e emsāl che goft? [What did the health minister discuss with maddāḥs about the mourning sessions of this Muharram?], 8 Mordad 1399/July 29, 2020, https://hamshahrionline.ir/x6z46.

83 For Muharram 2020, the Covid-19 version: ISNA (Iranian Students News Agency), Āyīn-e 'azādārī-e ḥosseinī dar emāmzādeh șāleh [Commemoration ritual in the Emamzadeh Saleh], 3 Sharivar 1399/August 24, 2020, https://www.isna.ir/photo/99060302127/. For Muharram 2018, a typical maddāḥ̄ performed by the famous maddāh Haj Mahmoud Karimi: https://www.youtube.com/ watch?v=GNn8NLlttVY.

84 On this topic, I have been inspired by Sally MacDonald, Stolen or Shared: Ancient Egypt at the Petrie Museum, in Jocelyn Hackforth-Jones and Mary Roberts, eds., Edges of Empire: Orientalism and Visual Culture (Malden, MA: Blackwell Publishing, 2005), pp. 162-80. Thanks to Mira Xenia Schwerda for bringing this article to my attention.

85 Souren Melikian, Destroying a Treasure: The Sad Story of a Manuscript, New York Times, April 27, 1996, https://www.nytimes.com/1996/o4/27/style/IHT-destroying-a-treasure-the-sad-story-of-a -manuscript.html. For manuscript desecration in the context of war, genocide, and survival, see Watenpaugh, The Missing Pages, which tracks the life of the Zeytun Gospels (1256) as a "survivor object" of the Armenian Genocide.

86 Christiane Gruber, The collectors who cut up a masterpiece, Prospect Magazine, October 17, 2019, https://www.prospectmagazine.co.uk/arts-and-books/gruber-figure-frieze-folio-islamic-art -christies.

87 To help nuance the classroom teaching of the Emamzadeh Yahya and comparable sites, I have included some of this research and photography in my module for MIT's Global Architectural History Teaching Collaborative (GAHTC) entitled A Global Historiography of Persian Architecture: The Making and Breaking of Iran's Cultural Heritage. See lecture 2, Medieval Persian Tilework between the Field and Museum.

88 Sally MacDonald's poses the latter question in her assessment of the Petrie Museum of Egyptian Archaeology in London. See MacDonald, Stolen or Shared, p. 178.

89 Kishwar Rizvi, The Other Side of Paradise, or 'Islamic' Architectures of Containment and Erasure, Platform, June 24, 2019, https://www.platformspace.net/home/the-other-side-of-paradise-or-islamic -architectures-of-containment-and-erasure.

9o Rigorous historiography is nothing new in Islamic art, and the pending 2021 Historians of Islamic Art Association conference is aptly titled "Regime Change." As this article was finalized in JulyOctober 2020, the academy and museum witnessed an unprecedented spike of programming and scholarship devoted to problematic sales, collections, and narratives. Among many, consider Contested Codices: The Legal, Ethical, \& Moral Ramifications for the Sale of Islamic Manuscripts Today, talk by Stephennie Mulder and Yael Rice, Virtual Islamic Art History Seminar Series, July 16 2020; Reimagining the Museum: 'Difficult' Objects (Workshop), University of Southern California, October 2, 2020; and CFP - 100 Histories of 100 Worlds in 1 Object, posted by Mirjam Brusius, HIAA listserve, October 14, 2020.

91 Many luster tiles have been recovered during excavation, meaning their original buildings are lost, a fraction of their former selves, or simply unknown. Takht-e Suleyman, excavated by the Deutsches Archäologisches Institute between 1959 and 1978, is a well-known source. A visit to the site offers an opportunity to see tile imprints in the flesh, especially in the standing lower walls of the west iwan and octagonal pavilions, and actual tiles on display in the site museum. For luster tiles and vessels excavated at Aveh, just west of Qom, see Arash Lashkari, Hamid Khatib Shahidi, and Somaye Mohajer Vatan, A Preliminary Report of Excavations at Aveh Plain, Islamic Period, Iranian Journal of Archaeological Studies 3 (2013), pp. 21-37.

92 Ritter, The Kashan Mihrab, pp. 172-3, has expressed similar sentiments. Although complete luster mihrabs of the Varamin and Natanz type are no longer in situ, we can consider alternative 
configurations, including the star-cross and luster-monochrome example in the Masjid-e 'Ali at Quhrud. See Oliver Watson, The Masjid-i 'Alī, Quhrūd: An Architectural and Epigraphic Survey, Iran 13 (1975), pl. Ia; Akbari, Kāshī va Kāshān, passim. The latter also includes images of luster tiles unearthed on the lower walls of the cenotaph of Habib b. Musa in the Emamzadeh Habib b. Musa at Kashan during the recent restoration of its żarịh. Also see Watson, Persian Lustre Ware, pl. 113 (the top of the cenotaph now in Tehran's Islamic Museum) and pl. 114 (in situ cenotaph tiles with animals and figures).

93 Eskan News, "Emāmzādeh Yahyā beh zūdī nāpadīd mīshavad!" An example of successful crowd sourcing by the British Museum is the video Hajj: Stories of the modern pilgrimage (https://www .youtube.com/watch? $\mathrm{v}=\mathrm{r}_{5} \mathrm{l}_{5}$ Cwge7yk), made to accompany the 2012 exhibition Hajj-journey to the heart of Islam. Also consider efforts of inclusive engagement at the Petrie Museum, including the writing of extended new labels by source communities. See MacDonald, Stolen or Shared, pp. 176-8. See, for example, the papers in Pamela Karimi and Nasser Rabat, eds., The Destruction of Cultural Heritage: From Napoléon to ISIS, an online book published by Aggregate, 2016, https://architecture .mit.edu/publication/destruction-cultural-heritage-napoléon-isis.

95 Haji-Qassemi, ed., Emamzadehs and Mausoleums, 82, cites a recent restoration to the entrance ayvān (iwan) that obscured a passage of stamped band-keshī.

96 For a history of the preservation of Ilkhanid sites in Iran, see Ana Marija Grbanovic, Some Remarks Regarding the Preservation of Ilkhanid Architectural Heritage in Iran: History, Challenges and Perspectives, in Joaquim Rodrigues dos Santos, ed., Preserving Transcultural Heritage: Your Way or My Way?: Questions on Authenticity, Identity and Patrimonial Proceedings in the Safeguarding of Architectural Heritage Created in the Meeting of Cultures (Casal de Cambra, Portugal: Caleidoscópio, 2017), pp. 799-810. 